Europako H2020 erakunde-esparruan, «hiri adimendunaren" ikuspegi nagusia apurka-apurka bilakatzen ari da herritarrengan ardaztutako «hiri esperimentala" deritzon beste paradigma batera. Bilakaera horrek berrikuntza sozialak ekarri baditu ere -adibidez, hiri-plataforma kooperatiboak loratzen ari dira, herritarrek (adimendunek) beren burua datuhornitzailetzat baino gehiago erabaki-hartzailetzat hartzen duten heinean-, datuen teknopolitikarekin zerikusia duten azpiko arazo etiko eta demokratiko batzuk konpontzeke daude oraindik.

Giltza-Hitzak: Hiri adimendunak. Living labs. Hiriplataforma kooperatiboak. Berrikuntza soziala. Europa. Datuen teknopolitika. Eskubide digitalak. Penta Helix.

El enfoque hegemónico de "ciudad inteligente" en el marco institucional europeo H2020 está evolucionando lentamente hacia un nuevo paradigma centrado en los ciudadanos llamado "ciudad experimental". Si bien esta evolución incorpora innovaciones sociales, incluidas las plataformas cooperativas urbanas que están floreciendo a medida que los ciudadanos (inteligentes) se consideran cada vez más tomadores de decisiones en lugar de proveedores de datos, ciertos problemas éticos y democráticos subyacentes relacionados con la tecnopolítica de los datos siguen sin resolverse.

Palabras Clave: Ciudades inteligentes. Living labs. Plataformas cooperativas urbanas. Innovación social. Europa. La tecnopolítica de los datos. Derechos digitales. Penta Helix.

L'approche hégémonique de "ville intelligente " dans le cadre institutionnel européen H2020 évolue lentement vers un nouveau paradigme centré sur le citoyen, appelé "ville expérimentale ". Bien que cette évolution intègre des innovations sociales, y compris les plates-formes de coopération urbaine florissantes au fur et à mesure que les citoyens (intelligents) se considèrent davantage comme des décideurs plutôt que comme des fournisseurs de données, certains problèmes éthiques et démocratiques sous-jacents liés à la technopolitique des données restent non résolus.

Mots-Clés : Villes intelligentes. Living labs. Platesformes coopératives urbaines. Innovation sociale. Europe. La technopolitique des données. Droits numériques. Penta Helix. 


\section{Deciphering Smart City Citizenship: The Techno-Politics of Data and Urban Co-operative Platforms}

To cite this article:

Calzada, I. (2018),

Deciphering Smart City Citizenship: The Techno-Politics of Data and Urban Co-operative Platforms.

RIEV, Revista Internacional de Estudios Vascos/International Journal on Basque Studies 63(1-2):42-81. DOI: 10.13140/RG.2.2.24498.35524/6.

To access journal version:

http://www.eusko-ikaskuntza.eus/en/publications/deciphering-smart-city-citizenship-the-techno-politics-of-dataand-urban-co-operative-platforms/art-24544/

To access to the preprint version:

https://www.researchgate.net/publication/334672459_Deciphering_Smart_City_Citizenship_The_TechnoPolitics_of_Data_and_Urban_Co-operative_Platforms

Calzada Mugica, Igor

University of Oxford. Urban Transformations ESRC \&

Oxford Programme for the Future of Cities, COMPAS

(ESRC Centre on Migration, Policy and Society)

58 Banbury Road, Oxford, OX2 6QS - UK

igor.calzada@compas.ox.ac.uk

www.orcid.org/0000-0002-4269-830X 
Calzada Mugica, Igor: Deciphering Smart City Citizenship: The Techno-Politics of Data and Urban...

\section{Introduction: smart city citizenship at stake in the European city-regional realm}

According to billionaire investor and philanthropist George Soros, the giant multinational technology firms Facebook and Google have become "obstacles to innovation, and are a menace to society" (Solon 2018:1). Amid hegemonic rhetoric about the promises of techno-centric smart cities (Angelo and Vormann 2018), Soros recently stated at the World Economic Forum that the "days are numbered for the two geek giants". Moreover, the digital philosopher Eugeny Morozov has argued that the economics of these giants' data extraction are creating a world in which they build addictive services to gather citizens' data to develop artificial intelligence (AI) and machine learning solutions for the very addiction problem they created (Morozov 2018).

Because of this timely debate, smart city citizenship is at stake in some European (smart) cities and regions, depending on how they react to the disruption to the techno-politics of data privacy, literacy, awareness, and ownership in their policies and communities caused by projects such as Google Urbanism (2018) and the "sharing economy' (exemplified by AirBnB, Uber, Cabify, and Amazon). At present, Barcelona is an archetypal case of a European city evolving towards a new citizencentric paradigm called the 'experimental city' (Calzada 2018a; 2018b). This contrasts with Toronto, Canada, where a controversial debate about privacy, identity, and security around data is taking place around the internationally renowned intervention called Sidewalk Labs, designed by Alphabet/Google (Sidewalk Labs 2018).

Although the relationship between technology and the city is long-standing, only since the 1990s has a clear set of terms or definitions been widely used to define certain types of approaches to cities and technologies, such as the e-city, electronic city, intelligent city, u-city, cyber city, and media city. These terms were developed as a consequence of the Internet and other computing technologies that spilled into European society and everyday city life. Information and communication networks began to significantly alter the social and structural life of the city and heralded new forms of civic governance, deliberation, and participation, as well as smart city citizenship (Willis and Aurigi 2018). As such, the current de- 
Calzada Mugica, Igor: Deciphering Smart City Citizenship: The Techno-Politics of Data and Urban...

bate about the suitability of a participatory and representative democracy is timely in the evolution of smart city citizenship and inevitably reflects on citizens' awareness of (big) data and (big) data's techno-political and psycho-political implications (Galparsoro 2017). These implications include transparency as "no longer just a desirable virtue in politics but an imperative tactic if the aim is to stay clear of disrepute" (Castells 2018:101). When Han (2015) denounced transparency, he did so as a call to action against this core restrictive element of contemporary societies -people's slavery to a data-driven lifestyle. He advocates a fundamental imperative: the need to allow experimentation in citizens' lives as an unpredictable work of art rather than a set of scientific urban rules that fix their lives as pure hyper-plugged 'geek' slavery (Calzada and Cobo 2015).

Smart cities are currently dealing with a remarkable amount of data being controlled by Al tools and devices owned by multinational corporations. This raises the question of how a smart city can ensure the privacy, identity, and security of its citizens while experimenting with intertwined representative and deliberative democratic public expressions. In response to this question, and closely following the contours of the smart city citizenship debate, there has been a counter-reaction fuelled by the interplay of certain multi-stakeholders, highlighting the need for an ethically transparent data-driven society that reinforces the digital rights of citizens through accountable data ethics (Han 2013; Susskind 2018). Even more recently, a wide range of manifests, declarations, and institutional frameworks have embodied this paradigm shift (Access now 2018; Asilomar 2018; Barcelona City Council 2018; IBM 2018; Montreal Declaration Responsible Al 2018; Telefónica 2018; Universidad de Deusto 2018). Therefore, this article aims to explain how a smart city could transition towards a more experimental urban approach, which would require rethinking data transparency, literacy, and democratic accountability based on a new deal or social contract on digital ethics and data rights.

The growing awareness of digital rights may affect the ethics of stakeholders (citizens and institutions) particularly through their interplay (helix thinking, Calzada and Cowie 2017). The unique role of stakeholders and their ethics may determine the balance experimental cities and regions in Europe strike between political and democratic endeavours in data-rich environments by changing the minds of unpopular critics of the technocratic smart cities. As a result of the negative side-effects of big data extraction monopolies in smart cities, the so-called 'data-opolies' (Stucke and Grunes 2017), a new set of research terms and findings are gradually surfacing, including ‘algorithmic oppression' (Noble 2018), 'platform capitalism' (Srnicek 2017; Rossi 2018), 'automating inequality' (Eubanks 2017), 'technically wrong' (WachterBoettcher 2017) and 'weapons of math destruction' (O’Neill 2008).

Although the concept of the 'smart city' has become the popular in recent years - even a brand, at least in Europe- the initial techno-centric smart city has evolved into a socially-constructed and citizen-centred 'smart city', which this paper refers to as the 'experimental city' (Evans et al. 2016). The so-called techno-centric smart city uses resources cleverly and attracts money, corporate power, and private industry by offering cheap, effective solutions to social and political problems in a functional, optimised, and safe fashion. However, these smart cities are not participatory, democratic, sustainable, or fair. This smart city notion employs 
Calzada Mugica, Igor: Deciphering Smart City Citizenship: The Techno-Politics of Data and Urban...

Han's (2015) notion of predictable and enslaving patterns forced by the 'digital and transparent society', in which the psycho-politics of data plays against individual freedom of choice, impoverishing citizens' lives through their own obsession with being controlled by big data and measured by numbers.

The smart city is a hyperconnected entity that bypasses human uniqueness, interaction capacity, and ability to self-organise transformational urban circumstances. In response to this hegemonic approach to the techno-centric smart city, the citizencentric, or experimental, city (based on unpredictable and creative psycho-political events, according to Han) is emerging through niche experiments that demonstrate far more nuanced democratic and co-operative service provision models for cities (Anastasiu 2019; Clamp and Alhamis 2010; Hacking Inside Black Box 2018; Keith and Calzada, 2018; Goldsmith and Kleiman 2017; Gupta 2014). This evidence reveals not only an awareness of data techno-politics and governance frameworks, but also a pursuit of alternative business models characterised by urban co-operative platforms, which may open up a new post-GDPR (General Data Protection Regulation) wave of social entrepreneurial activity on the European city-regional realm (Calzada 2017; European Data Protection Board 2018; Scholz 2016; Srnicek 2017). One such context to experiment is the EU's Horizon H2020 Smart Cities and Communities Lighthouse programme, which is the focus of the next section.

\section{The European smart city policy framework: h2020 smart cities and communities lighthouse projects}

From the institutional and geographic standpoints, the importance of city-regions in the EU is evident (Calzada 2015): 59\% of the EU population lives in metropolitan areas, which generate $62 \%$ of all employment and $68 \%$ of the EU's GDP. Alongside this trend, the European data economy could grow 18-fold under favourable policy and legislative conditions and could total 4\% of the EU's GDP by 2020. Europe is home to many vibrant cities, each with its own unique flavour (Calzada 2016a; 2017). Sprawling metropolises like London, Paris, and Berlin are renowned as global centres. Conversely, at least half of all EU cities are home to fewer than 100,000 people. In between, city-regional configurations of 1-3 million people are increasingly shaping daily economic and political scenarios by deeply affecting citizens' lives in terms of mobility, energy, employment, migration, democracy, and connectivity (Calzada and Keith 2018). While cities like Lisbon and Florence radiate renaissance charm, cities like Barcelona, Amsterdam, Naples, Torino, Bologna, Vienna, Glasgow, Bristol, Helsinki, Utrecht, Dublin, and Brussels are continually experimenting with new ways to set up city-centric approaches.

The brilliant diversity of Europe's cities should be treasured. However, the continent's city-regions though face shared challenges. Municipalities across Europe are racing to find solutions to troubles that transcend city limits and national boundaries. For example, virtually all European cities are grappling with the challenges of urban air pollution and chronic traffic congestion. Traffic jams cost the EU around $€ 100$ bn per year, while EU air quality standards are consistently breached in more than 130 European cities (European Commission 2016). 
Calzada Mugica, Igor: Deciphering Smart City Citizenship: The Techno-Politics of Data and Urban...
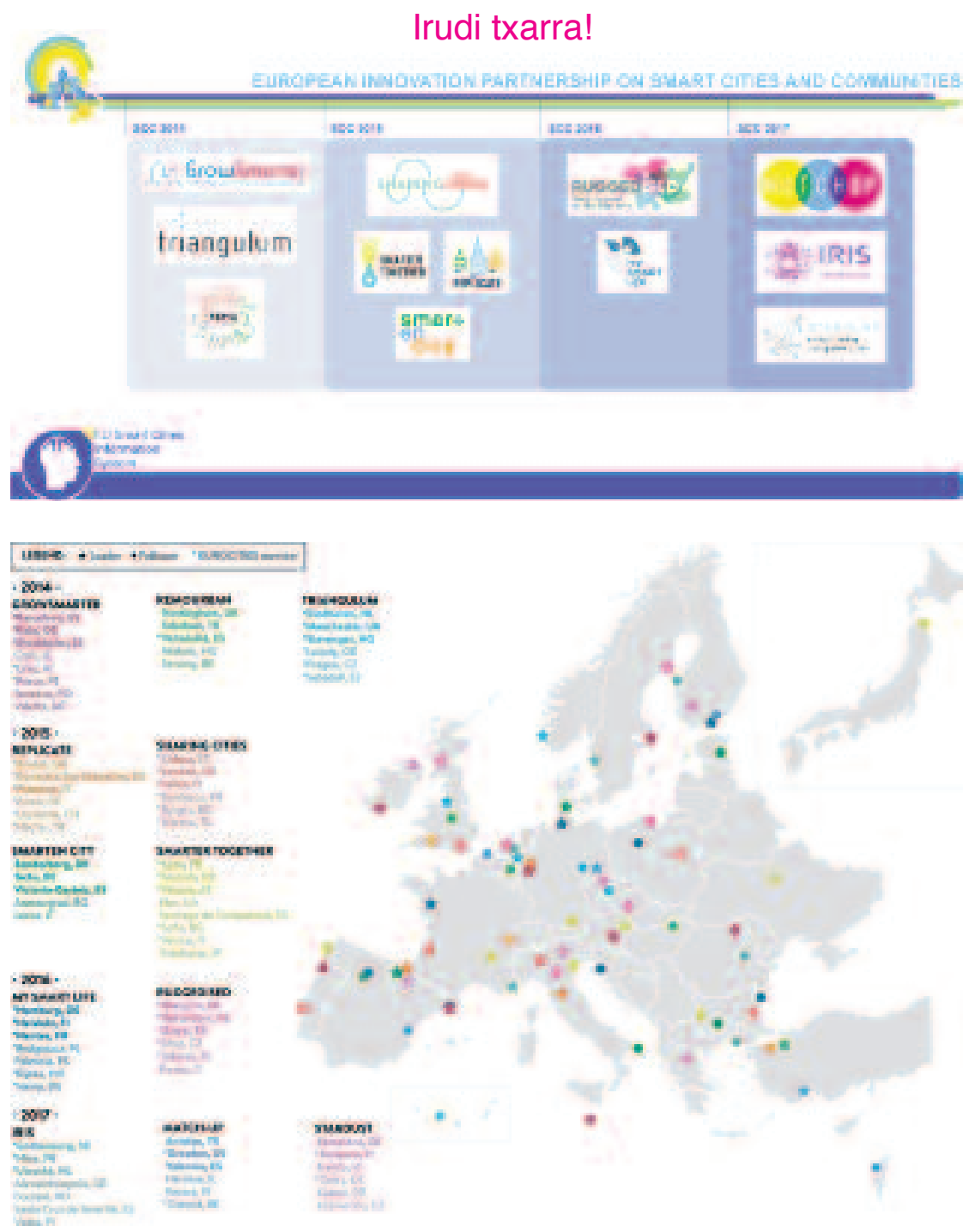

Figure 1. 12 EU H2O20 Lighthouse projects. (Source: @SmartCitiesSCIS) 
Calzada Mugica, Igor: Deciphering Smart City Citizenship: The Techno-Politics of Data and Urban...

According to the institutional rhetoric of the European Commission, smart city technologies are vital to ensure that cities (and by extension, metropolitan areas and regions) can answer the key social, political, democratic, economic, institutional, and environmental questions that current and future generations face (Caragliu, Del Bo, and Nijkamp 2011). The European Commission has invested $€ 280 \mathrm{~m}$ to establish the Horizon 2020 (H2020) framework called Smart Cities and Communities, which encompasses all 12 Lighthouse projects (European Commission 2018). The Lighthouse projects aim to deliver smart technologies to municipalities by demonstrating that technologies like electric cars and smart lampposts can be a cost-effective way of tackling some of the most profound problems facing city authorities. Since 2014, the 12 Smart Cities and Communities Lighthouse projects have focused on ensuring that people who live and work in cities can enjoy the quality-of-life benefits derived from innovative smart technologies (Figure 1).

In Sønderborg, innovative district heat networks are being established as part of the SmartEnCity project (2018). In Milan, under the Sharing Cities programme (2018), building retrofits are radically improving energy efficiency and reducing $\mathrm{CO} 2$ emissions. In Lyon, the Smarter Together programme is introducing an electric-vehicle car-sharing system and an autonomous driverless electric shuttle (2018). San Sebastian's Replicate programme has installed smart lampposts in a bid to slash city electricity costs (2018).

In the Basque Autonomous Community (Spain), three relevant projects are simultaneously taking place in the three capital cities of the city-region: Replicate in Donostia-St. Sebastian, SmartenCity in Vitoria-Gasteiz, and As-Fabrik in Bilbao (2018). Alongside these EU-funded projects, in the broad countours of the Basque city-region, the city of Pamplona-Iruñea was recently awarded the Stardust EUproject (2018). At the city-regional scale of the Basque Country (Calzada 2015), gradual efforts are attempting to provide an overarching strategic smart city-regional framework by connecting these lighthouse and strategic projects with a bottom-up network encompassing 232 'smart' municipalities in the Basque Autonomous Community. This initiative is funded by the Basque regional government through the Association of Basque Municipalities entitled EUDEL (Asociación de Municipios Vascos) via the strategic programme 'HerriSmartik: Smart Municipalities in the Basque Autonomous Community' (Calzada 2016b).

The $\mathrm{H} 2020$ institutional framework is based on the rationale that cities achieve more when they collaborate. The Lighthouse projects involve cities sharing technical learning, spreading the risk of investing in new technology, and using their scale to drive down costs via joint procurement. Technologies tested as part of the H2O2O Smart Cities and Communities Lighthouse programme can then be implemented on a wider scale at a vastly reduced cost per unit. Evidence suggests that joint procurement can generate massive cost savings for cities bold enough to embrace inter-city co-operation. For example, following a reorganisation of regional procurement in Austria in 2001, city authorities achieved savings of 30\% and an administrative workload reduction of 60\% (European Commission 2017a).

The Lighthouse projects involve 80 cities across Europe. They demonstrate the innovative potential of smart city technologies by allowing citizens to avert tur- 
Calzada Mugica, Igor: Deciphering Smart City Citizenship: The Techno-Politics of Data and Urban...

bulent, and many times obscure, extractivist algorithmic governance practices (Lane 2019; Lanier 2018; Van Der Zwan, Van Doorn, Duivestein and Pepping 2018; Wired 2018). Consequently, local authorities are already imposing certain data governance imperatives as a result of the GDPR, which took effect in May 2018 (European Data Protection Board 2018).

The future belongs to the European cities and regions that genuinely embrace city-to-city learning and attempt to fulfil the promise of smart cities (Coletta, Evans, Heaphy, and Kitchin 2018; Calzada and Cobo 2015; Calzada 2018b). However, new social, institutional, and political transitions are required to understand how some European city-regions face new challenges while avoiding the algorithmic control of big corporations. Therefore, the point of departure of this paper revolves around three underlying strategic underlying issues for smart cities in the $\mathrm{EU}$ in the years to come.

First, 'city-to-city-learning' programmes will likely become the standard replication strategy in cities rather than pure predictable 'replicability'. Pure replicability means "the possibility of transporting or copying results from a pilot case to other geographical areas" (European Commission 2017a:12; European Commission 2018; Bable 2018). At present, the 'city-to-city-learning' programme is being experimentally implemented by the Future of Cities Programme at the University of Oxford in the Replicate Lighthouse project (City2CityLearning 2018). It is also inspiring the programme HerriSmartik (Calzada 2016b)), which encompasses a network of municipalities in the Basque Autonomous Community. The 'city-to-city-learning' programme aims to revise the assumption that the city is a predictable and rational machinery. This issue is not addressed in this paper, but will be subject of a forthcoming publication.

Second, it is similarly likely that the techno-politics of data will lead to a permanent state of monitoring. In the hegemonic and techno-centric approach of smart cities, citizens are considered pure and passive data providers (Calzada 2018b). The current transition towards more socially-constructed experimental cities suggests a new role for smart city citizenship: decision-makers co-operatively setting up platforms to avoid the monopolistic control of extractivist multinationals' algorithmic governance. These companies have increased citizens' awareness of how (big) data disruption could modify urban ecosystems by requiring further regulations to prevent companies from sensoring, capturing, and monetarising data with no return to the communities in which they operate. This issue is discussed in the fourth and fifth sections of this paper.

Third, the potential emergence of urban co-operative platforms (Scholz 2016) as opposed to the hegemonic platform capitalistic paradigm (Srnicek 2017) may start an insightful policy debate. Certain transitions are occurring from the hegemonic techno-centric smart cities' business models, represented by the H2O2O official approach, to socially-constructed co-operative urban platforms evolving towards experimental cities. Many European cities are increasingly advocating for the latter. Some cities are working inside the $\mathrm{H} 2 \mathrm{O} 20$ funding framework, whereas others are not. According to recent preliminary findings by the author on the analysis of $\mathrm{H} 2 \mathrm{O} 2 \mathrm{O}$ fellow/follower cities (Replicate 2018), these cities are welcome to experiment with new business models beyond the public-private partnership (PPP) framework. 
Calzada Mugica, Igor: Deciphering Smart City Citizenship: The Techno-Politics of Data and Urban...

Hence, the aim of the paper is not to present a list of cities on one or the other side of this transition, but rather to describe this ongoing transition between (techno-centric) smart cities and (citizen-centric) experimental cities. However, a preliminary list of European cities currently driven by a citizen-centric approach includes Barcelona, Amsterdam, Naples, Torino, Bologna, Vienna, Glasgow, Bristol, Helsinki, Utrecht, Dublin, and Brussels. Further research is needed on this trend and to provide further evidence to support this transition.

This paper makes two contributions to the current literature on smart cities through the techno-politics of data and urban co-operative platforms. First, it enhances the current understanding of smart cities beyond techno-deterministic and data-driven approaches by further examining what smart city citizenship would mean in European cities. Second, it contributes to understanding two main factors that make this transition possible: (i) the techno-politics of data and (ii) urban co-operative platforms. Therefore, this paper can help policy makers, academics, private companies, NGOs, civic groups, entrepreneurs, and activists broaden the implementation of smart city projects by including citizens as decision-makers from the beginning, as citizens are essential for the democratic health of European city-regions (Urban Transformations 2018). Ultimately, deciphering the smart city citizenship will require a distinction between the hegemonic techno-centric smart city approach and the new ongoing alternative intervention approach (the experimental city). The experimental city should blend the interdependencies between various stakeholders in response to critiques that the smart city is overly technocratic and instrumental (Cardullo and Kitchin 2018).

Following the general introduction and the policy framework description, this paper presents a theoretical literature review on the term 'smart city' by emphasising ten transitions towards the 'experimental city' framework. After that, the fourth section demonstrates that citizens are considered active decision-makers rather than passive data providers in this ongoing transition. The fifth section discusses data issues and their techno-political implications for the current understanding of the smart city. The sixth section presents the main result of this paper, which is the notion of 'experimental cities' as a transitional citizenship framework encompassing three structural elements: (i) Urban Living Labs (ULLs), (ii) Data Commons, and (iii) Urban Co-operative Platforms. Finally, section 7 answers the three research questions formulated in the following section.

\section{Theoretical literature review: transitions from smart cities to experimental cities}

The term 'smart city' turns 25 this year. It was introduced in 1992, around the time of the historic Rio Earth Summit. Typing it into a search engine today will generate more than 15 million hits. Thus, figures for the smart city 'market' appear similarly impressive. Persistence Market Research forecasts that global growth will balloon from its current valuation of $\$ 622$ billion to $\$ 3.48$ trillion by 2026 , a fivefold increase in just one decade (McClelland 2017; Raconteur 2017). 
Calzada Mugica, Igor: Deciphering Smart City Citizenship: The Techno-Politics of Data and Urban...

The last 20 years of research on the smart city paradigm is fragmented and contested (Mora et al. 2017). Although it is emerging as a fast-growing topic of scientific inquiry, much of the knowledge generated about the smart city is centred on its technological in nature. Therefore, this paper investigates social and collective intelligence (smart citizenship), cultural artefacts (citizen watchdog groups), and environmental attributes (systemically sustainable), among other factors that need to be integrated into the current zeitgeist of urban innovation involving information communication technology (ICT), which is so far limited to the term 'smart city'.

According to Willis and Aurigi (2018), the terms in Table 1 below characterise cities on a spectrum. This spectrum ranges from initial explorations of computing effects on the city (the first cybercities in 1995 envisaged what would happen when information arteries provided all kinds of information and communication services to industries and households), through to the virtual city (an online representation of a real city) and the e-city, which envisaged new forms of governance and civic participation through online forums. In the first years of the $21^{\text {st }}$ century, these terms evolved into more city-centred terms, such as the digital city and u-city or ubiquitous city, which developed from the early internet networks and the potential of the city as a platform where people could interact and access city services in a range of ways. This notion that is directly connected with the term 'experimental city', which is explained in the sixth section.

Table 1. Smart cities' related terms from 1995-2016 (Willis and Aurigi 2018:7)

\begin{tabular}{|c|}
\hline - Cybercities \\
- City of bits \\
- Digital metropolis \\
- Real time city \\
- Digital places \\
- Network cities \\
- Digital city \\
- Virtual city \\
Electronic/e-city \\
- Mediacity \\
- Smart city \\
Augmented urban spaces \\
Urban informatics \\
- Ubiquitous/u-city \\
- Sentient city \\
Knowledge cities \\
- Hybrid city \\
- The city as interface \\
- Smart urbanism \\
- Netspaces \\
- Hackable city \\
IoT (Internet of Things) city
\end{tabular}


Calzada Mugica, Igor: Deciphering Smart City Citizenship: The Techno-Politics of Data and Urban...

With the rise of connected technologies of smart sensors and networks, the term 'smart city' was introduced in 2008 to capture these new forms of 'smart urbanism'. These are a selected set of terms that emphasise key stages of development, but many more terms exist that represent more nuanced and specific aspects of technological change and the city. Looking at how terms have developed over the last 30 years shows that as technology continues to develop, new terms and labels will be created to reflect the changing nature of technology's impact on the urban space and systems.

It is noteworthy that although smart cities (Albino et al. 2015; Krivý 2016; Ersoy 2017) are already being built, they diverge considerably from the simplistic, one-size-fits-all, smart-city-in-the-box approach that has dominated mainstream institutional approaches thus far (UK Government 2016; Díaz-Díaz et al. 2017; RICS 2017). This raises a number of questions: “(i) for whom and for what purpose are smart cities being developed? (ii) Are smart cities primarily about, or should they be about, (ii.1) creating new markets and profit, (ii.2) facilitating state control and regulation, or (ii.3) improving quality of life while enhancing citizens' opportunities to participate in democracy?" (Kitchin 2016:7; 2017).

The contemporary smart city cannot be reduced to the economic value that it generates through partnerships with powerful public and private actors (Rossi 2016; 2018). While the application of new information flows and the development of smart cities are receiving increasing attention, there is still limited understanding of the interconnections among hard and smart infrastructures and economic, political, and social systems on both metropolitan and regional scales. Furthermore, this conventional paradigm has often failed to deliver practical tools that can help people better understand and intervene in their daily realities while engaging with the various stakeholders that are important for European cities and regions. Hence, a multi-stakeholder approach is required to overcome dataism (Harari 2016a), understood as the logic that oversimplifies city metabolisms, seeing them as mere assemblages or systems of data and algorithms (Morozov 2014; Morozov and Harvey 2016; Morozov and Bria 2017; 2018; Morozov and Eno 2017) rather than as ecosystems of citizens (Devisch et al. 2016; Keith and Calzada 2016; Kontokosta 2016). In the sixth section, the importance of the transformational dimension of the multi-stakeholders' framework is explained by distinguishing the Triple, Quadruple and Penta Helix frameworks (see Figure 2 and Table 4).

The development and use of the buzzword 'smart city' in the planning of inner cities could be intimately connected to today's necessary urban transformations (Calzada 2016a). There is currently a great deal of rhetoric about the importance of building smart cities, but this rhetoric does not pay attention to the elements that constitute smart city strategies and policies in diverse contexts (Kitchin 2016). Technological solutions have often been proposed under the umbrella of the smart city buzzword without first considering citizens' needs, their ability to meet those needs and use the proposed solutions, or their socio-technical misalignment with the city itself (Campbell 2012; Hajer and Dassen 2014).

Thus, this paper suggests that European city-regions should first unpack or deconstruct ('un-plug') the meaning of smartness in their unique urban realities (Calzada and Cobo 2015) by asking ten underlying questions about the cities they 
Calzada Mugica, Igor: Deciphering Smart City Citizenship: The Techno-Politics of Data and Urban...

want to create. This exercise is suggested for cities in the EU that are directly or indirectly influenced by the H2O2O Smart Cities and Communities policy framework. As part of that, a wide range of stakeholders in cities and regions are debating the digital rights of citizens through accountable data ethics. These digital rights are: (i) the right to be forgotten on the Internet; (ii) the right to be unplugged; (iii) the right to a person's own digital legacy; (iii) the right of a person's personal integrity to be protected from technology; (iv) the right to freedom of speech on the Internet; (v) the right to a person's own digital identity; (vi) the right to the transparent and responsible usage of algorithms; (vii) the right to have a last human instance in the expert-based decision-making processes; (viii) the right to equal opportunities in the digital economy; (ix) the consumer rights in e-commerce; (x) the right to hold intellectual property on the Internet; (xi) the right to universal access to the Internet; (xii) the right to digital literacy; (xiii) the right to impartiality on the Internet; (xiv) the right to a secure Internet.

Safeguarding the digital rights of citizens through accountable data ethics involves 'unplugging' people's city experience, or making being digitally connected a smart experience for citizens. The questions below are related to the framework called 'Unplugging' (Calzada and Cobo 2015), which consists of ten transitions. Thus, each city-region can adopt these ten transitions from the smart cities approach and apply them to a new paradigm that this paper explores -that of experimental cities (Evans et al. 2016). The ten transitions and questions to move the smart city from a techno-centric to a citizen-centric approach are:

1. Who: Will the smart city evolve into an urban sphere in which dwellers have the right to decide whether to be connected? (Morozov 2017)

2. How: Is the city a social interface in which citizens can self-design their social and everyday needs? (Amin and Thrift 2016)

3. System: Will devices serve citizens more than citizens serve devices? (Friedewald and Pohoryles 2013)

4. Governance: Is the bottom-up innovation perspective wishful thinking? (If You Want To 2017; Webb and Mills 2016)

5. Information: In the era of data, is it possible to transition from controlled to open data-driven models? (Levy 1968)

6. Focus: Do citizens notice the difference between simple social interactions and human ties built on trust? (Shin and Shin 2016)

7. Space: Will citizens observe changes in which context-collapsed information will be contextualised to enhance social interactions? What are the implications for the privacy and security of individuals (Carrington 2016; Guerrini 2016)? Context collapse is a term used by academics (Marwick and Boyd 2010) writing about the effects of social media and the contexts they give rise to. As such, the term refers to an infinite number of contexts collapsing upon one another into a single moment of recording and having direct consequences for the public and private lives of citizens.

8. Design: How can the design of places and user interactions be improved to create an 'ambient commons' for citizens? The term 'ambient commons' (McCullough 2013) refers to the cognitive role of citizens in rela- 
Calzada Mugica, Igor: Deciphering Smart City Citizenship: The Techno-Politics of Data and Urban...

tion to fixed forms of architecture and the city itself when surrounded by a superabundant flow of ambient information where individual signals increasingly matter less.

9. Socio-political processes: Is a shift occurring in the power dynamics between stakeholders? (Blanco et al. 2017)

10. Political economy: Will the political economy of the smart city, and the related techno-politics of the data governance model, be altered by any changes in stakeholder power relations? (Stucke and Grunes 2017)

Only after unpacking the techno-deterministic view of our cities ('un-plugging') can citizens smartly connect ('plug') stakeholders into a wide, smart governance framework by including five types of actors, which this paper presents in the sub-section 6.2., by introducing the Penta Helix multi-stakeholder framework (Calzada 2016a, 2017). These stakeholders are the public sector, the private sector, academia, civic society, and social entrepreneurs/activists. It is necessary to 'plug' stakeholders in by setting up a new, complex, multi-stakeholder, city-regional urbanity to transition towards real smartness in cities and regions. A dynamic power balance between stakeholders has so far been lacking in the hegemonic, technocratic, and techno-centric version of the smart city (Cowley et al. 2017). Thus, the distinction among the helixes (groups of stakeholders) is methodological. By using the Penta Helix multi-stakeholders' framework, which stems from the social innovation perspective (Calzada 2016a), this paper aims to shed light on the transformational interplay created by social entrepreneurs/activists (the 'fifth helix') influencing the other stakeholders.

However, the position outlined in this paper avoids a dystopian view. Instead, it embraces a constructive notion that considers the favourable conditions that exist for a potential smart city policy agenda based on urban transformations driven by social innovation and experimentation (Sabato et al. 2017). Likewise, cities and regions represent powerful places in which to detect emerging processes and observe spontaneous urban transformations.

To summarise, after the negative side-effects of hyper-connected societies are minimised, technology-oriented pathways towards smart cities still offer unexplored opportunities for experimentation (Han 2015). Thus, European cities and regions should embrace the transitional experiments already underway in cities such as Barcelona, Amsterdam, Naples, Torino, Bologna, Vienna, Glasgow, Bristol, Helsinki, Utrecht, Dublin, and Brussels, among many other niche experiments going on at the microlevel scale (Calzada 2017; Smarticipate 2016; Urban Transformations 2018).

These ten transitions from the smart city to the experimental city paradigm lead to three open research questions regarding smart city citizenship, which constitute the core theme of this paper:

1. What prospects exist for alternative funding and alternative business models for (smart) cities? (Kourtit and Nijkamp 2012)

2. What practical/political interventions have been tried or are possible among businesses, local governments, academia, communities, and social entrepreneurs (Penta Helix framework)? (Calzada 2016a) 
Calzada Mugica, Igor: Deciphering Smart City Citizenship: The Techno-Politics of Data and Urban...

3. Is another type of (smart) city possible? That is, is there a 'third-way' between the state and the market that overcomes the PPP framework? (Keith and Calzada 2017)

\section{Rationale: (smart) citizens are active decision-makers rather than passive data providers}

Regarding smart citizenship, this paper asks whether alternatives to the technodeterministic approach to smart urbanism (Marvin et al. 2015) are flourishing. In the last few years, a new way of empowering the smart city through its smart citizens has received increased attention (Hemment and Townsend 2013; Waag 2016). Currently, cities such as Barcelona (Eizaguirre 2016; Eizaguirre and Parés 2018; Blanco et al. 2017) are embracing this new shift to an inclusive, democratic, and participative smart city by advertising accordingly: "If you'd rather have smart citizens than smart cities... BITS, 'Barcelona Initiative for Technological Sovereignty', will be in your interest" (BITS 2016). The Barcelona Digital Plan mostly follows Alex Pentland's (2014:x) principle that city-regions "[need] a 'New Deal on Data' putting citizens in control of data that is about them and also creating a 'data commons' to improve both government and private industry". This is essentially the source of the evolution from the smart city to the experimental city paradigm, which produces clear consequences in the political economy of data governance frameworks and the entrepreneurial urban ecosystem of cities through the methodological representation of the helixes (Triple, Quadruple, and Penta).

In a recent manifesto, advocates for smart citizens (Waag 2016) suggested that smart citizens should take responsibility for the places they live and work and the places they love, value access over ownership and contribution over power, ask for forgiveness, not permission, appropriate technology rather than accept it as-is, and provide assistance to those who are less 'tech savvy'. This set of principles shows that there is still a limited understanding of the interconnections between hard and smart infrastructures, as well as among economic, political, and social systems on metropolitan and regional scales. Furthermore, this new paradigm highlights the importance of overcoming the often-failed smart-city-in-a-box approach by engaging with the various stakeholders in European cities and regions.

In this direction, a study conducted in London called 'If You Want To', which developed "an urban co-operative platform to map, organise and make easily accessible green services or a sustainable lifestyle" (If You Want To 2017), has formulated an evidence-based view of (smart) citizens who are highly aware of their role in the world and the impact that even small individual choices may have globally. According to the preliminary conclusions of this study (Broadbent 2017), (smart) citizens are contextually aware of the decisions they make in their daily lives -and the consequences of these decisions- when interacting with the urban realm. This awareness of both the environmental and social impacts of personal practices does not, however, translate into a sense of renunciation. On the contrary, it translates into a sense of empowerment and commitment to do things better in a smarter way that can combine personal fulfilment with collective good. 
Calzada Mugica, Igor: Deciphering Smart City Citizenship: The Techno-Politics of Data and Urban...

Hence, this paper aims to rethink the dominant technocratic and technology-centric smart city discourse by presenting this new perspective on so-called smart citizens related to the emerging 'experimental city' paradigm. This new approach focusses not on imagining cities beyond or before technologies, but on accepting that city-regions are already fundamentally shaped by networked and mobile ICTs. This approach also focusses on thinking through the consequences for governance that the promises and realities of smart cities pose (Calzada 2013a). For example, many argue that smart city-regions will inevitably revolve around generating large amounts of data, and that this in itself will lead to new insights and governance strategies (Gray and Lämmerhirt 2017). However, as Acuto recently pointed out (2018: 165), "data availability does not immediately translate into better-informed urban management, nor fairer, greener, and more prosperous cities". City-regions are complex and are shaped by a wide variety of actors and organisations, which often have conflicting positions (Calzada 2015).

Likewise, data generated about individuals in cities and regions are variable, including personally identifiable information, data exhaust, personal data trails, and participatory personal data (Leao and Izadpahani 2016). Data about people is big data in both the cognitive sense and in the social movement sense (Shilton 2016:21). Actually, not all big data are data about people, but data about people inspire much of the hope and anxiety about their material, emotional and relational human conditions in an individual and collective way. As such, smart cities rely on data to provide and refine services that enhance the quality of citizens' lives, although this may impact personal privacy (Racounteur 2017). Thus, the aim of this paper is to unpack how citizens are usually framed within smart city initiatives and to examine the extent to which so-called 'citizen-centric' initiatives offer an alternative to, or simply reproduce, the actually existing neoliberal smart city.

According to Cardullo and Kitchin (2018), citizens in smart cities are consistent with neoliberal citizenship and its emphasis on personal autonomy and consumer choice, with individuals performing certain roles and taking responsibility for their circumstances (entrepreneurial self) and with the marketisation and privatisation of services and infrastructures (retreat of the state and austerity policy). While citizen participation is potentially widespread, it is most often framed in a post-political way that provides feedback, negotiation, participation, and creation, but in an instrumental rather than normative or political framework. In other words, citizens are encouraged to help provide solutions to practical issues -such as producing an app, providing feedback on a development plan, or performing certain roles/responsibilities- but not to challenge or replace the fundamental political rationalities shaping an issue or plan. Instead, most citizens are 'empowered' in the smart city by technologies that treat them as consumers or testers, people to be steered, controlled, and nudged to act in certain ways, or sources of data that can be turned into products. That is, citizens are treated as passive data providers. Citizens in the smart city perform within the bounds of expected and acceptable behaviour, rather than transgressing or resisting social and political norms as active decision-makers.

Another strand of the smart city debate emphasises the impact of the nearuniversal uptake of smartphones and other hand-held devices as well as the im- 
Calzada Mugica, Igor: Deciphering Smart City Citizenship: The Techno-Politics of Data and Urban...

pact of the internet of things-networks of data-gathering and cloud computing (Ratti and Claudel 2016). Many people use these devices and networks on a daily basis, but what this means for city-regional governance and the power-laden relationships among citizens, governments, and companies remains an open question. All this makes truly smart city-regional governance (Herrschel and Dierwechter 2015) exceedingly difficult, but at the same time, such governance is a fascinating and rewarding scale at which to investigate the various meanings and usages of smartness from the citizens' perspective. However, according to Tranos and Gertner (2012) and Leon (2017), the notion of smartness lacks a global inter-urban perspective, and, consequently, the gradual corporate acquisition of the smart city idea has been perpetuating capital accumulation by and among global cities at the international scale (Gaffney and Robertson 2016).

Recently, however, various research projects across Europe have begun to investigate alternative pathways to overcome the smartness lock-ins or entrenched ideas related to the notion of smart citizens. Most seek to develop both critical analyses and practical suggestions to tackle urban problems, such as pollution, health, safety, and mobility, through developing and using various types of mobile and networked data. These projects examine various ways of considering the interlinked notions of smart citizens and data where the so-called smart city approach has been enacted on the ground. Specifically, the research efforts sought to unpack and question the following three issues:

1. the types of knowledge gained through the production, distribution, and use of smart data (PWC 2016);

2. the role data play in the constitution of urban expertise and in mediating and transforming the relationships among smart citizens, governments, and companies (NESTA 2015); and

3. the ways in which data-driven knowledge and expertise tackle or reproduce inequalities in city-regions among diverse groups of (smart) citizens by provoking social exclusion patterns driven by toxic side-effects of technology (Hughes 2016).

Answering these questions shows that certain issues -such as the technopolitics of data and how smart citizens should be integrated into this realm of governance- remain crucial (Calzada 2017; Gray and Lämmerhirt 2017). The smart city approach is being deconstructed from many angles after having recently saturated policy agendas with very little reflection and being driven by market-based urban solutions. In response, a new smart-citizen-centric paradigm is being tested by examining the 'experimental city.' These urban experiments are intriguing, because "[they are] producing a different type of city by offering novel modes of engagement, governance, and politics that both challenge and complement conventional strategies such as on-going smart city strategies" (Evans et al. 2016:9).

This paper, therefore, explores what is new in the experimental city approach compared to the smart city approach. Cardullo and Kitchin (2018), based on Arnstein's classic contribution (1968), suggest a remarkable interpretation about the scaffold of smart citizen participation. However, more nuanced research is required for context-based applications. Therefore, in an attempt to contrast the two ap- 
Calzada Mugica, Igor: Deciphering Smart City Citizenship: The Techno-Politics of Data and Urban..

proaches and trace the evolution from one paradigm to the other, Table 2 shows ten transitions:

Table 2. From smart cities to experimental cities (elaborated by the author)

\begin{tabular}{|c|c|c|}
\hline Conceptual Transitions & Smart Cities & Experimental Cities \\
\hline $\begin{array}{l}\text { 1. (Smart) citizen } \\
\text { (Keith and Calzada 2016) }\end{array}$ & User/data provider & Decision-maker \\
\hline $\begin{array}{l}\text { 2. Technopolitics of data } \\
\text { (Louail et al. 2016) }\end{array}$ & Big data & Data sovereignty \\
\hline $\begin{array}{l}\text { 3. Notion of the city } \\
\text { (European Commission 2016; } \\
\text { Antiroikko 2013) }\end{array}$ & As a market & As a platform \\
\hline $\begin{array}{l}\text { 4. Personal data ownership } \\
\text { (Morozov 2014) }\end{array}$ & Owned by firms & Publicly scrutinized \\
\hline $\begin{array}{l}\text { 5. Stakeholder helixes } \\
\text { (Calzada 2016a) }\end{array}$ & $\begin{array}{l}\text { Triple or Quadruple } \\
\text { Helix }\end{array}$ & Penta Helix \\
\hline $\begin{array}{l}\text { 6. Business models } \\
\text { (Bollier 2016) }\end{array}$ & PPP & $\begin{array}{l}\text { Urban commons and } \\
\text { urban co-operative } \\
\text { platforms }\end{array}$ \\
\hline $\begin{array}{l}\text { 7. Scalability and replicability } \\
\text { (European Commission 2017a) }\end{array}$ & $\begin{array}{l}\text { Based on urban } \\
\text { solutionism }\end{array}$ & $\begin{array}{l}\text { Unpacking urban } \\
\text { problems }\end{array}$ \\
\hline $\begin{array}{l}\text { 8. Algorithmic coding } \\
\text { (Zanouda et al. 2017) }\end{array}$ & IoT sensor networks & Citizen-sensing \\
\hline $\begin{array}{l}\text { 9. Governance } \\
\text { (Almirall and Wareham 2011) }\end{array}$ & E-government systems & Living labs \\
\hline $\begin{array}{l}\text { 10. Causality } \\
\text { (Angelo and Vormann 2018) }\end{array}$ & Linear and normative & $\begin{array}{l}\text { Complex adaptive } \\
\text { systems and emergence }\end{array}$ \\
\hline
\end{tabular}

The information provided in Table 2 suggests that smart citizens are becoming the centre of current smart city transformations (Satyam and Calzada 2017). This argument emphasises three achievements of urban laboratories as new experimental settings (Karvonen and van Heur 2014): situatedness, change-orientation, and contingency. As such, data science could enable -or not enablecitizens' advice regarding the anticipation or even prediction of changes regarding the issues affecting people every day, which would help cities act sooner to prevent problems from escalating (NESTA 2015; Gray and Lämmerhirt 2017). 
Calzada Mugica, Igor: Deciphering Smart City Citizenship: The Techno-Politics of Data and Urban...

In short, (smart) citizens (Noveck 2015; Schuurman et al. 2016; Thomas et al. 2016) are considered decision-makers rather than simple data providers insofar as their decisions depend on a relational context and on their unique circumstances. Currently, within the scope of some approaches to experimental cities being implemented under the umbrella of Urban Living Labs (ULLs) interventions/methodologies (Almirall and Wareham 2011; Leminen 2015; Casual Synthesis Report 2016; Tõnurist et al. 2017), participants -as citizens- play more of an active role as coproducers than as mere data providers. However, the techno-politics of data (NESTA 2015), especially its ownership and governance, is an under-explored area of research. The next section discusses this area.

\section{Discussion: techno-politics and psycho-politics of data in smart cities}

According to the research firm Gartner (2016), 8.4 billion devices worldwide were connected to the Internet by the end of 2017, and this is expected to rise to 20.4 billion by 2020 . However, as previous sections in this paper highlight, some hesitation persists at the centre of the debate around what Harari (2016b) has described as dataism, or the religion or dogma of big data. Thus, what are the real consequences of big data for (smart) citizens? In response to this open question, Shilton (2016:21) argued that "uncertainties about how to use increasingly large sets of personal data are at the center of social debates about the virtues of Big Data. Not all big data are data about people, but data about people inspire much of the hope and anxiety bound up in discussions of the term." Thus, who controls not only data collection, analysis, storage, and usage, but ultimately ownership? Table 3, inspired by Shilton's question, shows the key parameters of the technopolitics and the psycho-politics of data related to the degree of citizen participation in today's cities. Shilton's interpretation assumes that users with high participation -smart citizens- can control the reuse of their own data. This assumption is a reaction to the fast development of the data extractivist practices by which (smart) citizens should not only be involved in participation processes, but also gain the knowledge and the ethical quality to engage autonomously in the data collection processes. The assumption may offer a way to implement data sovereignty, ownership, and commons policy frameworks. Hence, these are the key parameters in today's cities of the citizen participation in the techno-politics and psycho-politics of data collection, analysis, storage, reuse, and ownership.

Regarding new sources of data collection, analysis, storage, usage, and ownership, the major obstacles to fostering a people-centred data design are in the acquisition, shareability, and licensing restrictions of the obtained data. In this respect, closer collaboration is needed between computer scientists and social and political researchers regarding the development of stronger evidence-based research on how to tackle unexplored data issues. Thus, timely research should elaborate on the need to consider individuals not only as citizens deliberating on their material conditions but also as consumers agreeing and disagreeing to the terms of a service. Basically, this research could advocate for a more human-cen- 
Calzada Mugica, Igor: Deciphering Smart City Citizenship: The Techno-Politics of Data and Urban...

tred approach to the smart city-one that fosters interplay and interdependencies among multiple stakeholders.

When Habermas (2015) confronted technocratic and democratic smartness, he made it possible to generalise a category called smart citizens. As such, citizen interaction, engagement, involvement, participation, and deliberation are at the centre of debates around the techno-politics of data. However, how should the distrust, apathy, and open outrage that have become increasingly evident in popular political attitudes today be addressed? The misalignments between technology and the social needs of citizens in data generation constitutes a common dilemma today: will data-driven cities (PWC 2016) and devices continue to serve citizens or vice versa? In response to this question, different forms of engagement on the part of smart citizens can be discussed in relation to the techno-politics of data.

Table 3. Citizen participation in the techno-politics and in the psycho-politics of data collection, analysis, storage, reuse, and ownership (adapted from Shilton 2016:26)

\begin{tabular}{|c|c|c|c|c|c|}
\hline $\begin{array}{c}\text { Citizen } \\
\text { Participation } \\
\text { in the Techno- } \\
\text { politics and the } \\
\text { Psycho-politics } \\
\text { of Data }\end{array}$ & Collection & Analysis & Storage & Reuse & Ownership \\
\hline $\begin{array}{l}\text { High } \\
\text { participation }\end{array}$ & $\begin{array}{l}\text { Citizens } \\
\text { own or } \\
\text { control } \\
\text { devices; } \\
\text { data } \\
\text { collection } \\
\text { can be } \\
\text { customized }\end{array}$ & $\begin{array}{l}\text { Raw data } \\
\text { accessible; } \\
\text { citizens can } \\
\text { conduct } \\
\text { their own } \\
\text { analyses }\end{array}$ & $\begin{array}{l}\text { Data stored } \\
\text { on local } \\
\text { devices }\end{array}$ & $\begin{array}{l}\text { Citizens } \\
\text { control } \\
\text { reuse }\end{array}$ & $\begin{array}{l}\text { Citizens } \\
\text { own their } \\
\text { data and } \\
\text { customize } \\
\text { their data } \\
\text { policy }\end{array}$ \\
\hline $\begin{array}{l}\text { Low } \\
\text { participation }\end{array}$ & $\begin{array}{l}\text { Citizens } \\
\text { aware of } \\
\text { devices; } \\
\text { data } \\
\text { collection } \\
\text { can be } \\
\text { avoided }\end{array}$ & $\begin{array}{l}\text { Citizens } \\
\text { can see } \\
\text { visualizatio } \\
\text { ns or } \\
\text { analysis of } \\
\text { their data }\end{array}$ & $\begin{array}{l}\text { Data in } \\
\text { cloud } \\
\text { storage } \\
\text { with } \\
\text { options for } \\
\text { deletion }\end{array}$ & $\begin{array}{l}\text { Reuse is } \\
\text { restricted } \\
\text { to } \\
\text { aggregated } \\
\text { forms }\end{array}$ & $\begin{array}{l}\text { Data } \\
\text { collectors } \\
\text { use } \\
\text { contracts } \\
\text { to obtain } \\
\text { citizens' } \\
\text { consent } \\
\text { over their } \\
\text { own data }\end{array}$ \\
\hline $\begin{array}{l}\text { Little to no } \\
\text { participation }\end{array}$ & $\begin{array}{l}\text { Citizens } \\
\text { unaware of } \\
\text { devices; } \\
\text { data } \\
\text { collection } \\
\text { cannot be } \\
\text { avoided }\end{array}$ & $\begin{array}{l}\text { Citizens are } \\
\text { evaluated } \\
\text { or } \\
\text { categorized } \\
\text { without } \\
\text { their } \\
\text { knowledge }\end{array}$ & $\begin{array}{l}\text { Data in } \\
\text { cloud } \\
\text { storage } \\
\text { with no } \\
\text { option for } \\
\text { deletion }\end{array}$ & $\begin{array}{l}\text { Data } \\
\text { collectors } \\
\text { share or } \\
\text { sell data }\end{array}$ & $\begin{array}{l}\text { Data } \\
\text { collectors } \\
\text { own } \\
\text { citizens' } \\
\text { data }\end{array}$ \\
\hline
\end{tabular}


Calzada Mugica, Igor: Deciphering Smart City Citizenship: The Techno-Politics of Data and Urban...

As Morozov (2014) argued, despite the plethora of technological solutions to social problems, key questions remain unanswered: for example, who gets to implement data? and what kinds of politics of data do technological solutions smuggle through the back door? Discussions highlight how seemingly simple calls for data to be open challenge existing legal norms and have potentially profound implications for users along the value chain. For example, liability risks might be passed to the end user of open data, but what if end users cannot bear those risks? If the internet of things generates continuous monitoring and commonly individualized data, how should digital scholars theorize, regulate, and show the ethical choices (Hughes 2016) that have emerged around the legal liability surrounding the 'ownership of data'?

For a full understanding of the techno-political and psycho-political implications of the term smart city citizenship (Noveck 2015) and to fully actualise citizens' capacities as the main drivers of urban transformations, this paper underlines the need for a deeper transition towards experimental cities. Considering citizens as users or data providers assumes that personal data comprises a raw material that citizens take for granted as another element of the market. This should attract the attention of policy makers, as it involves underlying issues of value as well as political decisions.

Hence, citizens' data are intrinsic parts of their urban experience and their right to the city (Morozov and Harvey 2016). Why, then, are 'smart citizens' not considered pure decision-makers rather than passive data providers? Despite this willingness to pursue sustainable futures that are more democratic than technocratic, there is still strong inertia obstructing this alternative path. In fact, the current round of "urban experimentation differs from previous incarnations, indicating a specific type of governance fix for a neoliberal system that is struggling to move towards more sustainable forms of urban development" (Evans et al. 2016:10).

To open a new path of reflection and action based on Ostrom's influential thoughts on the commons (Ostrom 2010; Urban Transformations 2018), which have been analysed and adapted by Subirats (2012), this paper suggests breaking away from the individualistic vision conceived by the capitalist tradition. Subirats and Rendueles (2016) noted that this vision has progressively transferred the idea of rights to individual people. The resulting prevailing view is that only privatisation leads to growth (Mazzucato, 2018). However, Bollier (2016) argued that historically rooted individualisation processes are increasingly shaping people's communal conditions insofar as inter-subjectivity matters between them (Borch and Kornberger 2015). This notion could be fully applied to 'smartness' to explore an emerging paradigm that has not yet been established-the experimental city.

In a serious attempt to transition from the smart city to the experimental city, a deeper analysis of the techno-politics of data is needed to interpret the role of smart citizens as decision-makers rather than data providers. This notion is likely to be influenced by new conceptual explorations and empirical analyses of the urban commons (Bollier and Helfrich 2016) being applied to data (i.e., 'data commons'). To describe this current transition, this paper briefly presents three European projects on participatory smart cities that reconceptualise smart citizens as 
Calzada Mugica, Igor: Deciphering Smart City Citizenship: The Techno-Politics of Data and Urban...

decision-makers rather than data providers: HackAIR Project (2016), Flamenco Project (Flanders Mobile Enacted Citizen Observatories) (2016), and City of Things (2016). Together, these projects mark a transition from the smart city to the experimental city through their analyses of the techno-politics of data.

HackAIR is a social innovation project (Calzada 2013b; Sabato et al. 2017) and open technology platform for citizen observatories of air quality. The project focusses on citizen engagement and related strategies, such as crowdsourcing (citizens as sensors), distributed intelligence (citizens as basic interpreters), participatory science (citizens as participants in data collection), and extreme collaborative science (citizens as participants in defining problems and analysing data). The call to transition from the conception of citizens as data providers to citizens as decision-makers has provoked a powerful debate on the ethical dimensions of participatory innovative technologies.

The Flamenco project has developed this theme further, exploring how citizens can be empowered to tailor their own observatories based on participatory sensing and citizen science principles. An inter-disciplinary team is working on the applicability of the project from the perspectives of computer science and social science.

The City of Things project explores the experimental dimensions of data-driven living labs. These dimensions are related to multi-stakeholder co-creation processes for business, user design, prototyping, and product development. Basically, these are open innovation processes that aim to connect to the user experience during the product design process (West and Bogers 2016).

These projects demonstrate that what was once novel has become received wisdom. It is now common sense to suggest that the nature of the metropolis demands forms of knowledge that transcend the old boundaries that once divided the humanities, natural sciences, and social sciences. It has become almost self-evident that a model of knowledge production where knowledge is produced in the academy and then exported to city hall and local governance structures is inadequate for the metropolitan challenges of the $21^{\text {st }}$ century. Instead, the world has moved towards a stronger sense of co-production between research and practice. The idea that the questions arise in the real world, but the answers are found in the academy, is less plausible than ever. At its worst, the smart agenda, particularly as represented in journalistic accounts, can look like the return of technocratic determinism, through the back door, whereby all urban ills are resolved through scientific solutions. Such naïve arguments are, in reality, often the belief of second-rate technocrats and third-rate academic critics.

Interestingly, the complex and open systems of urban life are being disrupted by rapid social change and powerful economic forces (Keith and Calzada 2017). Recognising that such change is unpredictable in its disruptive form and uneven in its social consequences, one function of academic research is to speculate, test, map, and trace how disruptive technologies restructure the relationship between the individual and the city (Han 2015). The smart citizen at the heart of the new city needs to understand both the emancipatory potential and the divisive consequences of different moments of disruptive innovation. As described in the 
Calzada Mugica, Igor: Deciphering Smart City Citizenship: The Techno-Politics of Data and Urban...

next section, the function of Urban Living Labs (ULLS) (Karvonen and van Heur 2014) as forms of urban governance that act entirely as proxies among stakeholders is to show the choices at stake rather than to provide singular solutions to problems. How citizens make these choices then becomes a mediation of scientific expertise and deliberative democracy.

This section has highlighted how data-driven issues present new pathways for conducting research and implementing policy (Zanouda et al. 2017). However, to unpack data ('un-plug'), the underlying social, ethical, and political implications of the technical capacity to store and distribute information through the power of data science must be considered. Dystopian visions and technocratic utopias alike demand rigorous scrutiny in research and public debate to optimise the chance of shaping a better future city.

Concerning the ethical, psychological, and political dimensions of the ownership of data, urban experiments are gaining traction in cities all over the world as a way to stimulate alternatives and steer change (Caprotti and Cowley 2016). Policy makers, designers, private companies, and third sector organisations are initiating innovations to test alternative visions of local economic development, social cohesion, environmental protection, expansion of the creative sector, the evoIution of policy, service delivery, infrastructure provision, academic research, and more. The concept of experimentation feeds on the attractive notions of innovation and creativity (both individual and collective), while reframing the focus of sustainability from distant targets and government policies to concrete and achievable actions that can be undertaken by a wide variety of urban stakeholders in specific places. The ability of urban experiments to be radical in their ambitions while limited in their scope underpins a vibrant debate in both the policy and academic worlds regarding the ability of such experiments to initiate genuine change. Are these activities extensions of business as usual, spatially limited, and captured by a familiar cast of dominant interests? Or can they generate real alternatives and stimulate profound transformation?

To explore these questions, the next section reflects on the promises and perils of experimentation as an increasingly alternative framework of urban governance that is moving beyond the structural mistakes of the so-called smart city, which has been the dominant mode thus far.

\section{Results: experimental cities as a transitional citizenship phase?}

This section is divided into three sub-sections that discuss the three structural elements of the experimental city. In the first sub-section, (smart) citizens are situated within the milieu of the ULLs as a way in which experimentation occurs within the city. The second sub-section examines whether the commons can offer any alternative to PPPs by pursuing a 'third-way' of governing urban assets and enabling (smart) citizens to provide services themselves. The third sub-section explores the extent to which considering (smart) citizens as decision-makers or citizen makers in the broader realm of the city could create a potential ecosystem of urban cooperative platforms as alternatives to capital-based forms of business. 
Calzada Mugica, Igor: Deciphering Smart City Citizenship: The Techno-Politics of Data and Urban...

\subsection{Experimenting Within the City: Urban Living Labs (ULLs)}

In smart city and smart specialisation strategy $\left(\mathrm{S}^{3}\right)$ policy discourses (European Commission 2016, 2018), governance interventions have been proposed in European cities and regions without appropriately considering the stakeholders, their multiple expectations, and their visions of a possible and desirable urban future. As such, smart technological solutions have not always focussed on how technologies are used by (smart) citizens, and at times, the smart city's modes of governance have been misaligned with citizens and stakeholders.

In this context, to understand the inter-dependent challenges and opportunities for different stakeholders, this papers focusses on the dynamics of urban complexity, experimental research, and alternative policy approaches to cities and regions. This section is an invitation to rethink urban Europe based on the notion of an experimental laboratory that produces research and policy interventions. ULLs, exemplified by networks such as the European Network of Living Labs (ENoLL 2017), enact projects that include active user involvement, real-life settings, multistakeholder participation, multi-method approaches, and co-production.

In contrast, the smartness of some European urban strategies is dominated by a technological discourse centred on data aggregation represented by early adopter H2020 Lighthouse projects (round 2014), such as Triangulum, Remourban and, Growsmarter (see Figure 1), which allows the city-region to be managed by a fixed public-private partnership governance model. Nonetheless, in the complex multi-stakeholder urbanity that is flourishing around Europe, the shortcomings of the contemporary city must not be forgotten (Calzada 2016a).

Paralleling the mainstream approach of smart cities, urban laboratory initiatives, generally placed under the loose banner of ULLs (Urry 2014; Gascó 2017), have been increasingly emerging in the newest H2020 Lighthouse projects from the 2015 to 2017 (see Figure 1). They are seen as an approach to speeding up socio-technological innovation that involves multi-stakeholders in co-production processes and as a form of collective urban governance and experimentation within the city that addresses the sustainability challenges and opportunities created by urbanisation. Currently, the ways that city innovation policies propose highly spatially specific and potentially transformative stakeholder-helix strategies (Triple, Quadruple, or Penta) are worth examining. These policies recognise that strategies are cross-sectoral, involving the research base, private capital, and public expenditure of civil society. In the next sub-section, the suitability of expanding from Triple and Quadruple Helixes to the Penta Helix is described by suggesting that citizens require an active and entrepreneurial role among fixed institutional settings to ensure their full capacity as a system's transformers and as democratisers of urban life (Calzada and Cowie 2017).

The enormous potential for experimental forms of governance in many European city-regions is expressed by on-going ULL initiatives, such as the Urban Living Partnership (Birmingham, Bristol, Leeds, Newcastle, and York) (Urban Transformations 2017), JPI Urban Europe (2017), and many international programmes, such as ENoLL (2017), Mistra Urban Futures (2017), BMW Guggenheim Urban Labs (2017), Urban Lab + (2017), the Guangzhou International 
Calzada Mugica, Igor: Deciphering Smart City Citizenship: The Techno-Politics of Data and Urban...

Award for Urban Innovation (2017), Rockefeller 100 resilient cities (2017), GUST snapshots (2017), and urb@exp (2017).

The notion of ULLs is normally attributed to Professor William Mitchell of the Massachusetts Institute of Technology (MIT). MIT Living Labs (2017) aimed to bring together interdisciplinary experts to develop, deploy, and test -in actual living environments- new technologies and strategies for design that respond to this changing world. People from the outside world were invited into living laboratories where ethnographers and other researchers observed how they used newly invented information technology. Popularised in the USA, the notion generated traction in Europe; its diverse practices complicated what different actors believed the lab concept entailed. There have been numerous attempts to define a ULL, but there is no firm consensus in the literature. So, in what ways are ULLs, as the new experimental initiatives of the applied social sciences, the correct -or at least a feasible-type or scale of intervention? According to Spilhaus (1964:1141), "the city is a completely interacting system and thus, the experiment must be a total system. Nobody knows the answers to city living in the future, and, when answers are unknown, experiment is essential."

Despite the lack of consensus on the definition and building of ULLs in the emerging body of relevant policy initiatives and research (Keith and Calzada 2017), the following questions can explore how notions of experimentation inform new ways of urban living:

1. What does the integration of inter-disciplinary and place-based knowledge practices mean? How can urban studies bring together expertise in areas such as computing, mapping, politics, economics, digital anthropology, spatial analysis, and urban planning?

2. How can policy-makers address multi-stakeholder helix strategies? What 'are' the roles of the private sector, public authorities, academia, civil society, and entrepreneurs/activists in these ULL initiatives? What 'should' these roles be?

3. How can ULLs transcend the current governance constraints of the smart specialisation policy agenda in Europe?

4. What makes the ULL approach attractive and novel?

5. How are ULL initiatives being operationalised in contemporary urban governance initiatives for sustainability and in low carbon cities?

6. What prospects are there for alternative funding and alternative business models for cities and regions in Europe?

7. What are the practical and political interventions needed within multistakeholder approaches, and what are the potential concerns about data techno-politics?

8. Is another urban governance model possible-a 'third-way' between state and market? (OECD/KIPF 2016)

To operationalise the transition from the understanding of (smart) citizens as decision-makers rather than data providers, the next sub-section explores the notion of the urban commons, particularly through data commons, as related to the strategic role of institutions, in fostering regional ecosystems of experimenta- 
Calzada Mugica, Igor: Deciphering Smart City Citizenship: The Techno-Politics of Data and Urban..

tion that engage the public sector, the private sector, academia, civic society, and social entrepreneurs/activists in the Penta Helix framewok (see Figure 2). This endeavour focusses on experimentalism rather than smartness, which can help examine how urban governance requires considering the data commons beyond PPP.

Figure 2. Penta Helix multi-stakeholder framework (Calzada and Cowie 2017)

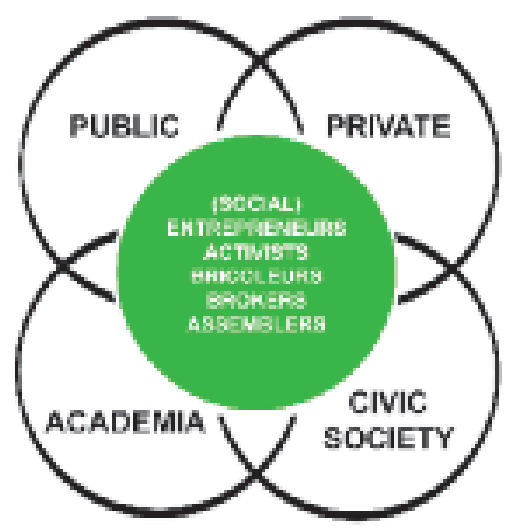

\subsection{Experimenting with the Data Commons: The Penta Helix Multi- Stakeholder Framework}

According to Karvonen and van Heur (2014), the experimental city approach champions the promise of experimental processes to promote urban innovations related to environmental protection, social cohesion, capitalist expansion, the development of the creative sector, policy improvements, infrastructure provision, academic research, and more. It is important to recognise that the notion of the experimental city is related to a wider discursive field that includes Triple-Helix early formations, applied innovation, engaged research, transdisciplinarity, living laboratories, and the co-production of knowledge. As such, experimental urbanism (Amin and Thrift 2016) taps into ideas of urban change as inherently multi-disciplinary, data-intensive, and embedded in place.

While the smart city approach was forged with an impetus towards urbansolution-driven fixes (European Commission 2016), the experimental city is based on three steps that unpack urban practices (Latour 1983:166):

"first, social scientists must capture the interests of non-scientists outside of the laboratory (in the field); second, they must collect information on real-world problems in the field and introduce this information into the controlled conditions of the laboratory to facilitate experimentation; and third, social scientists must extend the laboratory into wider society by carefully re-introducing the experimental results back into the field." 
Calzada Mugica, Igor: Deciphering Smart City Citizenship: The Techno-Politics of Data and Urban...

Thus, by emphasising the active role of (smart) citizenship, this paper includes the notion of the data commons in this narrative, as the rhetoric of the smart city has been entirely based on the idea of PPP. Regarding the techno-politics and the psycho-politics of data and the transition towards a more experimental city approach, it is important to understand that the debate over the data commons (Borch and Kornberger 2015; Foster and laione 2016) coincides with great technological changes that demand and invite urban scholars and practitioners to work both from a scientific perspective (to increase the capacity for innovation and cross-fertilisation) and from a social perspective (to ensure processes of social change and transformation). The data commons thus go beyond state-market relations (Subirats 2012). As such, at this stage of the paper, it is important to revisit the final research question. Is another type of city possible, that is, a 'third-way' between the state and the market, a city not dominated by PPP? A political debate is gathering around these ever-more-frequent conflicts that do not find an adequate response in the traditional market-state dichotomy (Blanco et al. 2017). What is the answer to this governance challenge?

Bollier and Helfrich (2016) suggest that cities are at a crossroads insofar as (smart) citizens could use the ideas of the data commons to retain control of the services that matter to them and to ensure that these services work for the people of the city, not just for businesses or the bureaucracy. However, the data commons could be abstract in its outcomes (Borch and Kornberger 2015). At this preliminary stage, the urban governance model should be evolving, which means that there should be a necessary transition from the Triple and Quadruple Helixes to the Penta Helix (Calzada 2016a). The prospect that the experimental city can overcome the limitations of the smart city offers a plethora of strategies for including more voices in the governance equation.

According to Lewontin (2000) and Leydesdorff and Fritsch (2006), the Triple Helix framework (made up of private/industry, public/government, and academia/university) enabled researchers to study the knowledge base of an urban economy in terms of civil society's support for the evolution of cities. However, dynamic and pervasive social innovation processes are not included in this analysis insofar as the definition of smart city governance only considers the fixed structure fuelled "by academia, industry, and government" (Deakin 2014:7). Even the recurring obsession with developing a full list of indicators using the Triple Helix for "smart city performance' (Lombardi et al. 2012; Michelucci et al. 2016) depicts this narrow vision, which fails to notice any pervasive and inter-dependent power interactions among stakeholders that ultimately defines the governance outcome.

The experimental city must include methodologically civic society (Quadruple Helix) and consider entrepreneurs/activists (Penta Helix) as part of the transition from the smart city approach. Deakin (2014:1) considers the Triple Helix framework sufficient to "cultivate the environmental capacity, ecology and vitality of those spaces which the direct democracy of their participatory governance open up, add value to and construct". However, this paper examines further connections between entrepreneurship and policy experimentation, as Sabato et al. (2017:18) suggested, by avoiding "narrow interpretations of social innovation", which could reinforce ongoing dynamics of welfare state retrenchment instead of its re-activation. 
Calzada Mugica, Igor: Deciphering Smart City Citizenship: The Techno-Politics of Data and Urban..

Given the current multi-stakeholder dynamics taking place in European cities and regions under the policy framework of H2O2O Smart Cities and Communities (Figure 1), transformative alliances among the public sector, the private sector, academia, and civic society should eventually include the fifth helix, embodied by social entrepreneurs and activists (i.e., intermediaries, bricoleurs, brokers, and/or assemblers), as the main driver of change. Further research is needed to explore the profiles, motivations, modes of interaction, and transformative conditions of this type of invisible but highly-influential stakeholder in the socio-economic and cultural life of the city (see Table 4 and Figure 2) (Calzada and Cowie 2017).

Recent projects, such as Smart Urban Intermediaries (2018), are clearly exploring this path-complementing the active role of social entrepreneurs and activists in local neighbourhoods as an integral part of the civic society. Nevertheless, it is worth distinguishing them methodologically as social entities. Conflating civic society ( $4^{\text {th }}$ helix) and the social entrepreneurs and activists ( $5^{\text {th }}$ helix) would leave out a powerful collective intelligence in communities that can nurture socially innovative processes based on local experimentation to tackle social inequalities. Triple Helix by itself does not suffice to activate unpredictable and experimental dynamics due to the fixed and technocratic nature of the interplay among stakeholders. Similarly, the Quadruple Helix, as it shown in Table 4, cannot leverage any intrinsic transformational reaction by itself, since it is based on an institutionalised bottom-up process, where citizens react passively to suggested initiatives.

Table 4. Rethinking Stakeholders' Helix Strategies

\begin{tabular}{|c|c|c|c|}
\hline & \multicolumn{3}{|c|}{ Rethinking Stakeholders' Helix Strategies } \\
\hline & Triple Helix (TH) & Quadruple Helix (QH) & Penta Helix (PH) \\
\hline Literature & $\begin{array}{l}\text { - Etzkowitz and } \\
\text { Leydesdorff } \\
2000\end{array}$ & $\begin{array}{l}\text { - Goddard and } \\
\text { Kempton } 2016\end{array}$ & $\begin{array}{l}\text { - Ostrom } 2010 \\
\text { - Anttiroiko } 2016 \\
\text { - Calzada } 2017 \text {, } \\
\text { 2018b }\end{array}$ \\
\hline $\begin{array}{l}\text { Multi- } \\
\text { Stakeholders }\end{array}$ & $\begin{array}{l}\text { - Public } \\
\text { - Private } \\
\text { - Academia }\end{array}$ & $\begin{array}{l}\text { - Public } \\
\text { - Private } \\
\text { - Academia } \\
\text { - Civic Society }\end{array}$ & $\begin{array}{l}\text { - Public } \\
\text { - Private } \\
\text { - Academia } \\
\text { - Civic Society } \\
\text { - Assemblers: (Social) } \\
\text { Entrepreneurs or/and } \\
\text { Activists }\end{array}$ \\
\hline Paradigms & PPP & Civic Universities & Urban Commons \\
\hline $\begin{array}{l}\text { Governance } \\
\text { Scheme and } \\
\text { Citizenship } \\
\text { Response }\end{array}$ & $\begin{array}{l}\text { Invisible and } \\
\text { Passive } \\
\text { Citizenship }\end{array}$ & $\begin{array}{l}\text { Reactive and Passive } \\
\text { Citizenship }\end{array}$ & $\begin{array}{l}\text { Proactive } \\
\text { Citizenship }\end{array}$ \\
\hline $\begin{array}{l}\text { Techno-Politics } \\
\text { of Data }\end{array}$ & $\begin{array}{l}\text { Technocratic } \\
\text { Top-Down }\end{array}$ & $\begin{array}{l}\text { Institutionalised } \\
\text { Bottom-Up }\end{array}$ & $\begin{array}{l}\text { Emergent and Complex } \\
\text { Bottom-Up }\end{array}$ \\
\hline
\end{tabular}


Calzada Mugica, Igor: Deciphering Smart City Citizenship: The Techno-Politics of Data and Urban...

As processes based on Quadruple Helix framework have revealed, the initiatives are pushed by institutions, resulting in poor or even inexistent mobilisation. Furthermore, neither the Triple nor the Quadruple Helix frameworks can articulate a deeper transformational democratic disruption entirely led and governed by a collective intelligence. However, data-driven sensitive urban environments require the valuable role of intermediaries as social entrepreneurs and activists (i.e., transformers and bricoleurs). Ultimately, it is essential to bring back the social ties that modern hyper-connected societies have dramatically diluted through the spread of data-rich fragmented environments. Therefore, it is vital to rethink multi-stakeholders' helix strategies that rely on the techno-political awareness of data. Yet this cannot occur while taking for granted the valuable role of proactive stakeholders who set up new collective connections based on the interplay among a diverse set of interests, imaginaries, and practices (Lombardi et al. 2011; Poppen and Decker 2018).

Hence, in the laboratory context, experiments regarding the data commons should ensure the complete representation of diverse voices from each helix. This would reflect a wide range of voices in a community without relegating any to institutional settings. The inherent instability of an experimentally driven city provides a mechanism for co-evolution and a capacity to process the transition from the smart city approach. Often, the dynamics of social innovation (Calzada 2013b) have been forgotten by those fostering urban change.

\subsection{Experimenting Towards Urban Co-operative Platforms? The City as a Platform and (Smart) Citizens as Maker Citizens}

Ultimately, the third structural element of the experimental city is the understanding of the city as a platform (Anttiroiko 2013, 2016) and of (smart) citizens as 'maker citizens' (Levy 1968; The Atlantic 2015; European Commission 2017b). Local authorities provide a wide range of services, including users' involvement in product development and citizens' right to bring up their concerns to in open innovation systems. Forms of participation may vary-some are nominal, some are transformative. More transformative modes of participation are associated with opening public data sets for public use free of charge and are related to the open source and user innovation movements (Smarticipate 2016). On the whole, these modes reflect the increasing intersection between the Penta Helix, driven by (social) entrepreneurs/activists, and the experimental notion of the data commons.

The inclusion of the fifth helix, broadly understood as those agents playing the role of transformational intermediaries (i.e., bricoleurs, brokers, or assemblers) in pursuit of social entrepreneurship and activism, connects directly to these early adopters with an ethical awareness of data and social justice. These agents are ultimately the source of the collective and experimental disruption, as Srnicek argued (2017:128): "More radically, we can push for post-capitalist platforms that make use of the data collected by these platforms in order to distribute resources, enable democratic participation, and generate further technological development. Perhaps today we must collectivise the platforms". Additionally, these agents could initiate a new generation of co-operative platforms including (i) co-operatively 
Calzada Mugica, Igor: Deciphering Smart City Citizenship: The Techno-Politics of Data and Urban...

owned online labour brokerages and market places, (ii) city-owned platform cooperatives, (iii) producer-owned platforms, (iv) union-backed labour platforms, (v) co-operatives from within, and ultimately, (vi) the platform as protocol (Scholz 2016). Will experimenting with data in cities pushed by the fifth helix mean evolving from 'platform capitalism' (Srnicek 2017) to 'co-operative platforms' (Scholz 2016)? Who will begin this 'platform revolution' and how will this happen (Parker et al. 2016)?

To some extent, a balance between private and public interests is complemented by other activities that could be considered the seeds of the experimental city in the realm of the data commons. As such, there are inherent asymmetries in the levels of engagement of firms and citizens, and these asymmetries are compensated for by welfare structures. Understanding the city as a platform may be a less controversial view of how to legitimise urban laboratories while redistributing capital and reducing inequalities at the neighbourhood level through the 'RobinHood effect' (Louail et al. 2016), enabling citizens to build and use the data platforms and make their own decisions based on urban co-operatives, as in Barcelona (Morozov and Bria 2018; Urban I-Lab 2018; Digital Social Innovation 2018; La Borda 2015).

In the realm of the experimental city, (smart) citizens should play a transformative role as decision-makers. In addition, the way some cities are evolving towards the power of the maker culture is related to the emergence of citizens as makers. The initiatives Barcelona and Amsterdam are implementing based on the 'decentralised citizens owned data ecosystem' fuelled by 'blockchain' technology through the Decode EU project are remarkable (Decode 2018). Taking the lead on this experimental strategy, Barcelona has set up Decidim.barcelona as a participatory process allowing data and algorithmic transparency for their (smart) citizens (Decidim 2018). The offline and online co-operative urban platforms are blended in a new 'data commons' strategy through ULLs, as 'Maker District Poblenou' is illustrating with a network of FabLabs (Maker District Poblenou 2018). Likewise, other cities, such as London, have established a network of makers in diverse disciplines (Open Workshop Network 2017), which creates further experimentation in the city.

Although this type of experimentalism resonates with entrepreneurial models of socio-economic systems, which have been implemented in different parts of the world for decades, some models in the realm of co-operativism have also been heavily researched (Dildorth 2014; Wanyama 2014). According to the ILO (2002:2), a co-operative is "an autonomous association of people united voluntarily to meet their 'common' economic, social and cultural needs and aspirations through jointly-owned and democratically-controlled enterprises". This is the case of the Mondragon co-operatives in the Basque Country (Spain) (Calzada 2013b; Clamp and Alhamis 2010; Gupta 2014), a paradigmatic business model far from the capitalistic business-as-usual type that includes the Penta Helix multi-stakeholder framework at the city-regional level, thus driving economic efficiency, territorial development, and social cohesion.

Even this model, however, shows some inherent contradictions that require further analysis. Mondragon co-operatives have been facing two complementary 
Calzada Mugica, Igor: Deciphering Smart City Citizenship: The Techno-Politics of Data and Urban...

crises for a number of years. The pressure of the global markets is undermining the cohesive model based on local employment, as the crisis in the Fagor flagship firm showed some years ago. As a result of the first crisis, the governance model has revealed a hierarchical conflict between the top management and the workers. The most substantial lesson learned (Calzada 2013b) has also raised an unresolved question: how can regionally rooted co-operative principles and values survive, be updated and re-activated in the $21^{\text {st }}$ century? By refounding a new type of co-operative entrepreneurship based on start-ups and spin-offs? Could these co-operatives be established by network-driven millennials/entrepreneurs under organisational frameworks based on open innovation, which would be sustainable but strongly fixed? To sum up, there is a need for an updated urban co-operative platform version based on inter-dependent metropolitan inclusiveness and regionally rooted social capital.

In conclusion, this paper questions whether the establishment of an ecosystem of urban co-operative platforms could begin a movement towards experimental cities. Some of the hypotheses presented in this paper (including the evolution of citizens as decision-makers, increasing awareness of the smart city's techno-political and psycho-political implications, growing interdependence among stakeholders, and the trend towards urban laboratories) create pathways towards urban co-operative platforms in energy, mobility, and ICTs-three sectors defined by the Smart City and Communities H2O2O policy framework, while the smart city approach is developing increasingly more sophisticated business models in European neighbourhoods (Müller and Rommel 2010), cities (Calzada 2018b), and regions (Cooperatives Europe 2017).

\section{Conclusion}

This paper examined the ongoing transition of the notion of (smart) citizens from data providers (extracted from the smart city dominant paradigm) to decision-makers (according to the emergent experimental city alternative paradigm). To conclude this paper, the three research questions are answered:

1. What prospects exist for alternative funding and alternative business models to move beyond smart cities by establishing the new paradigm of experimental cities?

In the current experimental realm, the way in which some urban experiments are modifying the ownership of capital -and in parallel, the ownership of data- could offer interesting pathways to establishing alternative funding and business models based on the awareness and ownership of data. Unlike those who argue that data privacy is not an issue because "people are happy to give away their personal data if it makes their life easier or more fun" (Raconteur 2017:6), new business models may arise based on community-based and community-controlled data that could follow more democratic socio-economic models, such as co-operative platforms/firms for self-managing urban issues. 
Calzada Mugica, Igor: Deciphering Smart City Citizenship: The Techno-Politics of Data and Urban...

2. What practical/political interventions have been tried or are possible among businesses, local governments, academia, communities, and social entrepreneurs?

In light of some smart city interventions, ULL experiments highlight new interdependencies among stakeholders while fostering ecosystems of entrepreneurial starts-up and SMEs. However, as Foster and laione (2016:1) suggest from the perspective of the city as a 'commons', "collaborative and polycentric governance strategies should recognise that private ownership rights must sometimes yield to the common good or community interest". Nonetheless, this paper presents the Penta Helix multi-stakeholder framework as a policy tool by pointing out the active role of the fifth helix, which includes social entrepreneurs, activists, bricoleurs, brokers, and assemblers.

3. Ultimately, is another type of (smart) city possible -that is, a 'third-way' between the state and market- that could overcome the PPP framework?

So far, PPP has been the primary model reinforcing the alliance between the state and market. As Hall (2015:3) notes, "PPP are used to conceal public borrowing, while providing long-term state guarantees for profits to private companies". However, several cities and regions, such as Barcelona, Amsterdam, Naples, Torino, Bologna, Vienna, Glasgow, Bristol, Helsinki, Utrecht, Dublin, and Brussels, among many others, (Calzada 2017) are currently undertaking experimental approaches that are likely to open up a 'third-way', led by urban co-operative platforms in the European city-regional realm (Mazzucato 2018).

However, smartness may not be appealing after being seen as technocratic, while the experimental approach has yet to be entirely established as a paradigm, so the open question here is how (smart) citizens will be able to decide, control, govern, and manage their urban futures by being both conscious of their rights to the city and aware of their duties in the processes of city making.

\section{Disclosure statement}

The authors have no conflicts of interest to declare. 
Calzada Mugica, Igor: Deciphering Smart City Citizenship: The Techno-Politics of Data and Urban...

\section{References}

ACCESS NOW. Human rights in the age of
artificial intelligence. Retrieved from
https://www.accessnow.org/. Accessed on
December 10, 2018.
ACUTO, Michele. "Global science for city
policy". Science. 359(6372):165-166. 2018.

ALBINO, Vito; Umberto BERARDI and Rosa Maria DANGELICO. "Smart Cities: Definitions, Dimensions, Performance, and Initiatives". Journal of Urban Technology. 22(1):3-21. 2015

ALMIRALL, Esteve and Jonathan WAREHAM. "Living Labs: Arbiters of Mid-and Ground-level Innovation," Technology Analysis \& Strategic Management 23(1):87-102. 2011.

AMIN, Ash and Nigel THRIFT. Seeing Like a City. Cambridge: Polity. 2016.

ANASTASIU, Irina. "Unpacking the Smart City Through the Lens of the Right to the City: A Taxonomy as a Way Forward in Participatory City-Making," in Michael DE LANGE; Martijn WALL. (Eds) The Hackable City: Digital Media and Collaborative City-Making in the Network Society. Singapore: Springer Singapore. 2019.

ANGELO, Hillary; VORMANN, Boris. "Long waves of urban reform". City. 1-19. 2018 doi: 10.1080/13604813.2018.1549850.

ANTTIROIKO, Ari-Veikko. "City-As-A-Platform: Towards Citizen-centred Platform Governance," paper presented at RSA Winter Conference 2016 on New Pressures on Cities and Regions, London, UK, 24-25 November 2016.

ANTTIROIKO, Ari-Veikko; Pekka VALKAMA and Stephen J. BAILEY. "Smart Cities in the New Service Economy: Building Platforms for Smart Services," Ai \& Society 29(3):323334. 2013.

ARNSTEIN, Sherry R. "A ladder of citizen participation". Journal of the American Institute of Planners. 35(4):216-224. 1968.

AS-FABRIK. Retrieved from https://www.uiainitiative.eu/en/uia-cities/bilbao. Accessed on December 24, 2018.

ASILOMAR. Asilomar Al Principles. Retrieved from https://futureoflife.org/ai-principles/?cnreloaded $=1 \& \mathrm{cn}$-reloaded $=1$ Accessed on December 10, 2018.
Barcelona City Council. Ethical Digital Standards: A Policy Toolkit - Barcelona. Retrieved from https://www.barcelona.cat/ digitalstandards/en/init/0.1/index.html Accessed on December 10, 2018.

BABLE. Retrieved from www.bablesmartcities.eu Accessed on January 29, 2018.

BITS (Barcelona Initiative for Technological Sovereignty). Retrieved from https://bits.city/. Accessed on December 10, 2016.

BLANCO, Ismael; Yunailis SALAZAR and Iolanda BIANCHI. Transforming Barcelona's Urban Model? Limits and Potentials for Radical Change Under A Radical Left Government. Retrieved from http://www.urban transformations.ox.ac.uk/blog/2017/transfor ming-barcelonas-urban-model-limits-andpotentials-for-radical-change-under-a-radical-I eft-government/. Accessed on March 19, 2017.

BMW Guggenheim Urban Labs. Retrieved from http://www.bmwguggenheimlab.org/. Accessed on March 21, 2017.

BOLLIER, David. The City as a Commons. Retrieved from https://www.youtube.com/ watch? $\mathrm{v}=\mathrm{z} 3 \mathrm{itmhDuem8}$. Accessed on February 1, 2016.

BOLLIER, David and Silke HELFRICH. Patterns of Commoning, The Commons Strategies Group Retrieved from http://bollier.org/blog/ spanish-translation\%E2\%80\%9Cthink-commoner\%E2\%80\%9Dnow-published. Accesed on March 19, 2016.

BORCH, Christian and Martin KORNBERGER. Urban Commons: Rethinking the City. London: Routledge. 2015.

BROADBENT, Stefana. How Smart Citizens Live. Retrieved from https://www.thersa.org/ discover/publications-and-articles/rsacomment/2017/how-smart-citizens-live. Accessed on March 19, 2017.

CALZADA, Igor. Data Devolution in Europe. ESADE MSc Speaker Series: Big Data \& Smart Cities. Retrieved from https:// www.youtube.com/watch? $v=i P 8 L V Q W r d J 0$. Accessed on January 29, 2018a. 
Calzada Mugica, Igor: Deciphering Smart City Citizenship: The Techno-Politics of Data and Urban...

\author{
-. "(Smart) Citizens from Data Providers to \\ Decision-Makers? The Case Study of \\ Barcelona". Sustainability 10(9):3252. \\ 2018b.
}

—. "The Techno-Politics of Data and Smart Devolution in City-Regions: Comparing Glasgow, Bristol, Barcelona, and Bilbao". Systems 5(1):18. 2017.

-. HERRISMARTIK: Basque Smart CityRegional Strategy in the H2020 European Context / La Estrategia Vasca de Territorio Inteligente en el Contexto Europeo Horizonte 2020: De la Agenda Digital Municipal a la Gobernanza de la Ciudad-Región Vasca Inteligente - HERRISMARTIK commissioned by EUDEL (Basque Municipalities' Association), LKS Consultancy and the Basque Regional Government,

Entrepreneurship, Innovation and Information Society Department. Zumaia: Translokal Academic Entrepreneurship for Policy Making. ISBN: 978-84-946385-1-0. DOI: 10.13140/RG.2.2.10932.76161. 2016b.

-. "(Un)Plugging Smart Cities with Urban Transformations: Towards Multistakeholder City-Regional Complex Urbanity?". URBS, Revista de Estudios Urbanos y Ciencias Sociales Journal 6(2):25-45. 2016 a.

—. "Benchmarking Future City-regions Beyond Nation-states". Regional Studies, Regional Science 2(1):351-362. 2015.

—. "Critical Social Innovation in the Smart City Era for a City-Regional European Horizon 2020," Journal of Public Policies \& Territory P3T 2(6). 2013a; 1-20.

—. "Knowledge Building \& Organizational Behaviour: Mondragon Case". In Frank MOULAERT; Diana MACCALLUM; Abid MEHMOOD; Abdelillah HAMDOUCH (eds.): International Handbook of Social Innovation. Social Innovation: Collective action, Social Learning and Transdisciplinary Research. Cheltenham: Edward Elgar (UK) Publishing. 2013b; 219-229 p.

CALZADA, Igor and Cristobal COBO. "Unplugging: Deconstructing the Smart City" Journal of Urban Technology 22(1):23-43. 2015.

CALZADA, Igor and Paul COWIE. "Beyond Data-Driven Smart City-Regions? Rethinking Stakeholder-Helixes Strategies". Regions 208(4):25-28. 2017.
CALZADA, Igor and Michael KEITH. Bridging European Urban Transformations Workshop Series 2016-2018. DOI: 10.13140/RG.2.2.32474.39365. 2018.

CAMPBELL, Tim. Beyond Smart Cities: How Cities Network, Learn and Innovate. Oxon: Earthscan. 2012.

CAPROTTI, Federico and Robert COWLEY. "Interrogating Urban Experiments". Urban Geography. 2016. DOI: 10.1080.02723638.2016.1265870.

CARAGLIU, Andrea; DEL BO, Chiara and Pert NIJKAMP. "Smart Cities in Europe". Journal of Urban Technology 18(2):65-82. 2011.

CARDULLO, Paolo and Rob KITCHIN. "Being a 'citizen' in the smart city: up and down the scaffold of smart citizen participation in Dublin, Ireland". GeoJournal 78(4). 2018. https://doi.org/10.1007/s10708-018-9845-8

CARRINGTON, Daisy. Yinchuan Smart City Future. CNN. Retrieved from http://edition.cnn.com/2016/10/10/asia/yinch uan-smart-city-future. Accessed on December 10, 2016.

CASUAL SYNTHESIS REPORT. "Co-creating Attractive and Sustainable Urban Areas and Lifestyles: Exploring New Forms of Inclusive Urban Governance". Nordregio \& JPI Urban Europe. (2016).

CASTELLS, Manuel. "Democracy in the age of the internet". Retrieved from https://lull.cat/IMAGES_175/transfer06not01.pdf. Access on December 10, 2018.

CITY OF THINGS: Discover Today the Possibilities of Tomorrow's Smart Cities. Retrieved from https://www.iminds.be/en/ succeed-with-digital-research/go-to-markettesting/city-of-thing. Accessed on December 10, 2016.

CITY-TO-CITY-LEARNING PROGRAMME.

Retrieved from https://replicate-

project.eu/city2citylearning/. Accessed on December 26, 2018.

CLAMP, Christina and Innocentus ALHAMIS. "Social Entrepreneurship in the Mondragon Co-operative Corporation and the Challenges of Successful Replication". The Journal of Entrepreneurship 19(2):149-177. 2010.

COLETTA, Claudio; Leighton EVANS; Liam HEAPHY and Rob KITCHIN. Creating Smart Cities. Oxon: Routledge. 2018. 
Calzada Mugica, Igor: Deciphering Smart City Citizenship: The Techno-Politics of Data and Urban...

COOPERATIVES EUROPE, The European region of the International Co-operative Alliance. Retrieved from

https://coopseurope.coop/about-cooperatives. Accessed on March 21, 2017.

COWLEY, Robert; Simon JOSS and Youri DAYOT. "The Smart City and its Publics: Insights from Across Six UK Cities," Urban Research \& Practice. 1-25. 2017. DOI: 10.1080/17535069.2017.1293150

DEAKIN, Mark. "Smart Cities: The State-ofthe-art and Governance Challenge", Triple Helix 1: (1)7. 2014.

DECIDIM project. Retrieved from https://www.decidim.barcelona/. Access on January 29, 2018.

DECODE project. Retrieved from https://www.decodeproject.eu/. Access on January 29, 2018.

DEVISH, Oswald; Alenka POPLIN and Simona SOFRONIE. "The Gamification of Civic Participation: Two Experiments in Improving the Skills of Citizens to Reflect Collectively on Spatial Issues". Journal of Urban Technology. 23(2):81-102. 2016.

DÍAZ-DÍAZ, Raimundo; Luis MUÑOZ and Daniel PÉREZ-GONZÁLEZ. "The Business Model Evaluation Tool for Smart Cities: Application to SmartSantander Use Cases," Energies. 10(3):262. 2017.

DIGITAL SOCIAL INNOVATION. Retrieved from http://ajuntament.barcelona.cat/digital/en/dig tal-innovation/digital-economy/digital-socialinnovation-programme-dsi4bcn. Access on December 29, 2018.

DILDORTH, Richardson. "Urban Cooperatives and Economic Development". Drexel Policy Notes 1(2):1-11. 2014.

EIZAGURRE, Santiago and Marc PARÉS. "Communities making social change from below. Social innovation and democratic leadership in two disenfranchised neighbourhoods in Barcelona". Urban Research \& Practice. 1-19. 2018. DOI: 10.1080/17535069.2018.1426782.

EIZAGURRE, Santiago. "Comparing Social Innovation Initiatives in Barcelona and Bilbao. Looking at Associate Participation in the Governance of Citizens' Rights". Revista Catalana de Sociología. 31(1):19-33. 2016. DOI: 10.2436/20.3005.01.69.
ENoLL (European Network of Living Labs). Retrieved from www.openlivinglabs.eu. Accessed on March 19, 2017.

ERSOY, Aksel. "Smart Cities as a Mechanism Towards a Broader Understanding of Infrastructure Interdependencies," Regional Studies, Regional Science 4(1):1-6. 2017.

EUBANKS, Virginia. Automating Inequality: How High-Tech Tools Profile, Policy, and Punish the Poor. NYC: St. Martin's Press. 2017.

EUROPEAN COMMISSION. Horizon 2020:

Two Years On. Brussels: European Commission. 2016.

EUROPEAN COMMISSION. The making of a smart city: replication and scale-up of innovation in Europe. Brussels: EU Smart Cities Information System. 2017a.

EUROPEAN COMMISSION, European Maker Week. Retrieved from https://blogs.ec. europa.eu/eupolicylab/european-maker-weekdrawing-citizens-to-the-maker-world/. Accessed on March 21, $2017 \mathrm{~b}$.

EUROPEAN COMMISSION. EU Smart Cities Information System. Brussels: EU Smart cities Information System. Retrieved from http://smartcities-infosystem.eu/sites-projects/ projects Accessed on January 29, 2018.

EUROPEAN DATA PROTECTION BOARD.

Guidelines 3/2018 on the territorial scope of the GDPR (Article 3) - Version for public consultation.

EVANS, James; Andrew KARVONEN and Rob RAVEN. The experimental city. London and New York: Routledge. 2016.

ETZKOWITZ, Henry and Loet LEYDESDORFF. "The dynamics of innovation: from National Systems and "Mode 2" to a Triple Helix of university-industry-government relations," Research Policy 29:109-123. 2000.

Flamenco Project: Flanders Mobile Enacted Citizen Observatories. Retrieved from www.citizen-observatory.be. Accessed on December 10, 2016.

FOSTER, Sheila and Christian IAIONE. "The City as a Commons", Yale Law \& Policy Review 34: 2. Article 2. 2016.

FRIEDEWALD, Michael and Ronald J. POHORYLES. "Technology and Privacy", Innovation: The European Journal of Social Science Research 26(1-2):1-6. 2013. 
Calzada Mugica, Igor: Deciphering Smart City Citizenship: The Techno-Politics of Data and Urban...

GAFFNEY, Christopher and Cerianne ROBERTSON. "Smarter than Smart: Rio de Janeiro's Flawed Emergence as a Smart City". Journal of Urban Technology. 1-18. 2016.

GALPARSORO, José Ignacio. "Big Data y Psicopolítica. Vía de escape: de la vida calculable a la vida como obra de arte," Dilemata 24:25-43. 2017.

GARTNER. Gartner Says Smart Cities Will Use 1.6 Billion Connected Things in 2016. Retrieved from http://www.gartner.com/ newsroom/id/3175418. Accessed on December 10, 2016.

GASCÓ, Mila. "Living Labs: Implementing Open Innovation in the Public Sector". Government Information Quarterly 34(1): 90-98. 2017.

GODDARD, John and Louise KEMPTON. The Civic University: Universities in leadership and management of place. Warwick: University of Warwick.

GOLDSMITH, Stephen and Neil KELIMAN. A New City O/S: The Power of Open, Collaborative, and Distributed Governance. Washington: Brookings. 2017.

GOOGLE URBANISM, Retrieved from www.googleurbanism.com. Accessed on January 29, 2018.

GRAY, Jonathan and Danny LAMMERHIRT. Data and The City: How Can Public Data Infrastructures Change Lives in Urban Regions. Cambridge: Open Knowledge. 2017.

Guangzhou Award. Retrieved from http://www.guangzhouaward.org/. Accessed on March 21, 2017.

GUERRINI, Federico. Forbes Cities cannot be reduced to just big data and loT: Smart City Lessons From Yinchuan, China. Forbes. Retrieved from http://www.forbes.com/ sites/federicoguerrini/2016/09/19/engagingcitizens-or-just-managing-them-smart-city-les sons-from-china/\#6a5a34392dda. Accessed on December 10, 2016.

GUPTA, Clare. "The co-operative model as a "living experiment in democracy". Journal of Co-operative Organization and Management 2(2):98-107. 2014.

GUST (Governance of Urban Sustainable Transitions). Retrieved from http://www.urban livinglabs.net/. Accessed on March 21, 2017.
HABERMAS, Jurgen. The Lure of Technocracy. New York, USA: Polity Press. 2015.

HACKAIR PROJECT: Collective Awareness for Air Quality, Retrieved from www.hackair.eu. Accessed on December 10, 2016.

HACKING INSIDE BLACK BOX. Abrir las instituciones desde dentro. 2018.

HAJER, Maarten and Ton DASSEN, Smart about Cities: Visualising the Challenge for 21st Century Urbanism. Amsterdam: Nai010 Publishers. 2014.

HALL, David. Why Public-Private Partnerships Don't Work: The Many Advantages of the Public Alternative. University of Greenwich, UK: PSIRU. Public Services International Research Unit, 2015.

HAN, Byung-Chul. The Transparency Society. Standford, USA: Standford University Press. 2015.

HARARI, Yuval Noah. Homo Deus: A Brief History of Tomorrow. London, UK: HarvillSecker. 2016a.

HARARI, Yuval Noah. Yuval Noah Harari on Big Data, Google and the End of Free Will. Financial Times. 2016. Retrieved from https://www.ft.com/content/50bb4830-6a4c11e6-ae5b-a7cc5dd5a28c. Accessed on November 10, 2016b.

HEMMENT, Drew and Anthony, TOWNSEND. Smart Citizens. Manchester: Future Everything Publications. 2013.

HERRSCHEL, Tassilo and Yonn DIERWECHTER. "Smart City-Regional Governance: A ‘Dual Transition'”. Regions Magazine. 300(1):20-21. 2015.

HUGHES, Bob. The Bleeding Edge: Why Technology Turns Toxix in an Unequal World. Canada: New Internationalist Publications Ltd. 2016.

IBM. IBM Everyday Ethics for Artificial Intelligence \& Trust and Transparency in Al. Retrieved from https://www.ibm.com/watson/ ai-ethics/ and https://www.ibm.com/ watson/trust-transparency/. Accessed on December 10, 2018.

If You Want To. Retrieved from https://iywto. com/. Accessed on March 18, 2017.

ILO (International Labour Organisation). Recommendation 193 Concerning the Promotion of Cooperatives, Geneva: ILO. 2002. 
Calzada Mugica, Igor: Deciphering Smart City Citizenship: The Techno-Politics of Data and Urban...

JPI-Urban Europe. Retrieved from http://jpiurbaneurope.eu/. Accessed on March 21, 2017.

KARVONEN, Andrew and Bas VAN HEUR. "Urban Laboratories: Experiments in Reworking Cities". International Journal of Urban and Regional Research 38(2): 379392. 2014.

KEITH, Michael and Igor CALZADA. "European Smart Citizens as Decision Makers Rather Than Data Providers", Urban Transformations ESRC report on 14th November 2016 Workshop Entitled '(Un)Plugging Data in Smart City-Regions'. 2016.

KEITH, Michael and Igor CALZADA. "European Urban Living Labs As Experimental City-to-City Learning Platforms". Urban Transformations ESRC report on 13th February 2017 Workshop entitled 'Experimenting with Urban Living Labs (ULLs) Beyond Smart CityRegions'. 2017.

KEITH, Michael and Igor CALZADA. "Back to the 'Urban Commons'? Social Innovation through New Co-operative Forms in Europe". Urban Transformations ESRC report on 12th February 2018 Workshop entitled 'Rethinking the Urban Commons in European CityRegions'. 2018.

KITCHIN, Rob. "Reframing, Reimagining and Remaking Smart Cities". The Programmable City Working Paper 20. 2016.

-. "Urban Science: A Short Primer". The Programmable City Working Paper 23. 2017. KONTOKOSTA, Constantine E. "The Quantified Community and Neighborhood Labs: A Framework for Computational Urban Science and Civic Technology Innovation". Journal of Urban Technology 23(4):67-84. 2016.

KOURTIT, Karima and Peter NIJKAMP. "Smart Cities in the Innovation Age," Innovation: The European Journal of Social Science Research 25(2):93-95. 2012.

KRIVY, Maroš. "Towards a Critique of Cybernetic Urbanism: The Smart City and the Society of Control," Planning Theory.1-23. 2016. DOI: 1473095216645631.

LA BORDA. Retrieved from https://vimeo.com/143976280. Accessed on March 21, 2015.

LANE, Jeffrey. The Digital Street. Oxford: Oxford University Press. 2019.
LANIER, Jaron. Ten Arguments for Deleting Your Social Media Accounts Right Now. New York: Henry Holt and Company. 2018.

LATOUR, Bruno. "Give Me a Laboratory and I Will Raise the World," in K. knorr-Cetina and M. Mulkay eds., Science Observed: Perspectives on the Social Study of Science. London: Sage Publications. 141-170. 1983.

LEAO, Simone and Parisa IZADPAHANI. "Factors Motivating Citizen Engagement in Mobile Sensing: Insights from a Survey of Non-Participants". Journal of Urban Technology 23(4):85-103. 2016.

LEMINEN, Seppo. “Living Labs as Open Innovation Networks: Networks, Roles and Innovation Outcomes". Doctoral Dissertations 132. (2015).

LEON, Joshua K. "Global cities at any cost". City. 1-19. 2017. DOI: 10.1080.13604813.2016.1263491.

LEVY, Steven. Hackers: Heroes of the Computer Revolution. New York: Dell Publishing. 1968.

LEWONTIN, Richard C. Gene, Organismo E Ambiente. Cambridge, MA/London: Harvard University Press. 2000.

LEYDESDORFF, Loet and Michael FRITSCH. "Measuring the Knowledge Base of Regional Innovation Systems in Germany in Terms of a Triple Helix Dynamics". Research Policy 35(10):1538-1553. 2006.

LOMBARDI, Patrizia; Silvia GIORDANO; Hend, FAROUH; Wael, YOUSEF. "Modelling the Smart City Performance," Innovation: The European Journal of Social Science Research 25: 2. 137-149. 2012.

LOMBARDI, Patrizia; Silvia GIORDANO; Andrea Caragliu; Chiara DEL BO; Mark DEAKIN; Peter NIJKAMP; Karima KOURTIT. An advanced triple-helix network model for smart cities performance. Research Memorandum. 2011.

LOUAIL, Thomas; Maxime LENORMAND; Juan Murillo ARIAS; José J. RAMASCO.

"Crowdsourcing the Robin Hood Effect in Cities". Physics and Society. 2016. arXiv: 1604.08394.

MAKER DISTRICT POBLENOU. Retrieved from http://ajuntament.barcelona.cat/digital/en/digi tal-innovation/make-in-bcn/maker-district. Accessed on 29 January, 2018. 
Calzada Mugica, Igor: Deciphering Smart City Citizenship: The Techno-Politics of Data and Urban...

MARVIN, Simon; Andrés LUQUE-AYALA and Colin MCFARLANE. Smart Urbanism: Utopian Vision or False Dawn? New York: Routledge. 2015.

MARWICK, Alice E. and Danah BOYD. "I Tweet Honestly, I Tweet Passionately: Twitter Users, Context Collapse, and the Imagined Audience," New Media \& Society 13(1): 114-133. 2010.

MAZZUCATO, Mariana. The Value of Everything: Making and Taking in the Global Economy. London: Penguin.

MCCLELLAND, Jim. What Being 'Smart' Means for Cities. Racounteur (2017) Retrieved from https://www.raconteur.net/ technology/what-being-smart-means-for-cities Accessed on March 10, 2017.

MCCULLOUGH, Malcolm. Ambient Commons: Attention in the Age of Embodied Information. Cambridge, MA: MIT Press. 2013.

MICHELUCCI, Fania Valeria; Alberto DE MARCO; Adriano TANDA. "Defining the Role of the Smart-City Manager: An Analysis of Responsibilities and Skills", Journal of Urban Technology 23(3):23-42. 2016.

Mistra Urban Futures. Retrieved from http://www.mistraurbanfutures.org/en. Accessed on March 21, 2017.

MIT Living Labs. Retrieved from http://livinglab. mit.edu/. Accessed on March 21, 2017.

Montreal Declaration Responsible Al. Retrieved from https://www.montreal declaration-responsibleai.com/the-declaration Accessed on December 10, 2018.

MORA, Luka, Roberto BOLICI and Mark DEAKIN. "The First Two Decades of SmartCity Research:A Bibliometric Analysis". Journal of Urban Technology 24(1): 3-27. 2017.

MOROZOV, Eugeny. Will tech giants move on from the internet, now we've all been harvested? The Guardian. Retrieved from https://www.theguardian.com/technology/201 8/jan/28/morozov-artificial-intelligence-datatechnology-online?CMP=share_btn_tw Accessed on January 29, 2018.

MOROZOV, Eugeny. So You Want to Switch Off Digitally? I'm Afraid that Will Cost You... The Guardian. Retrieved from https://www. theguardian.com/commentisfree/2017/feb/19/ right-to-disconnect-digital-gig-economy- evgeny-morozov. Accessed on March 19, 2017.

MOROZOV, Eugeny. The rise of data and the death of politics. Retrieved from https:// www.theguardian.com/technology/2014/jul/2 0/rise-of-data-death-of-politics-evgenymorozov-algorithmic-regulation. Accessed November 10, 2014.

MOROZOV, Eugeny and Francesca BRIA. Rethinking the Smart City. Democratising Urban Technology. New York: Rosa Luxemburg Stiftung. 2018.

MOROZOV, Eugeny and Francesca BRIA. Roundtable Session - A New Deal on Data: What Role for Cities? Smart City Expo World Congress. Retrieved from https://www.youtube.com/watch?v=1cakaaip 2Vw Accessed February 1, 2017.

MOROZOV, Eugeny and Brian ENO. Debat. Brian Eno i Evgeny Morozov Una conversa sobre tecnologia i democràcia. CCCB. Retrieved from https://vimeo.com/ 206060710. Accessed February 28, 2017.

MOROZOV, Eugeny and David HARVEY. Conversation between Evgeny Morozov and David Harvey. http://davidharvey.org/2016/ 11/video-conversation-between-david-harveyevgeny-morozov-on-post-neoliberalism-trump -infrastructure-sharing-economy-smart-city/. Accessed November 10, 2016.

MÜLLER, Jakob and Jens ROMMEL. Is there a future role for urban electricity cooperatives? The case of Greenpeace Energy. 7th Biennial International Workshop-Advances in Energy Studies. 2010.

NESTA. Data for Good: How Big and Open Data can be used for the Common Good. London: NESTA. 2015.

NOBLE, Safiya Umoja. Algorithms of Oppression: How Search Engines Reinforce Racism. New York: New York University Press. 2018.

NOVECK, Beth Simone. Smart Citizens, Smarter State: The Technologies of Expertise and the Future of Governing. Cambridge, MA: Harvard University Press. 2015.

OECD/KIPF, Fiscal Federalism 2016: Making Decentralisation Work. Paris: OECD Publishing. 2016. Retrieved from http://dx.doi.org/10.1787/9789264254053en. Accessed on November 10, 2016. 
Calzada Mugica, Igor: Deciphering Smart City Citizenship: The Techno-Politics of Data and Urban...

O'NEILL, Cathy. Weapons of Math Destruction: How Big Data Inequality and Threatens Democracy. London: Penguin Random House. 2008.

OPEN WORKSHOP NETWORK. Retrieved from www.openworkshopnetwork.com. Accessed on March 21, 2017.

OSTROM, Elinor. "Beyond Markets and States: Polycentric Governance of Complex Economic Systems," American Economic Review. 100:1-33. 2010.

PARKER, G. Geoffrey; Marshall W. VAN ALSTYNE and Sangeet Paul CHOUDARY. Platform Revolution: How networked markets are transforming the economy and how to make them work for you. NY: Norton. 2016.

PENTLAND, Alex. Social Physics: How social networks can make us smarter. New York: Penguin. 2014.

POPPEN, Florian and Reinhold DECKER. "The intermediary as an institutional entrepreneur: Institutional change and stability in TripleHelix cooperation". Triple Helix. 5(1):9. 2018.

PWC. From Concept to Applied Solutions: Data-driven Cities. London: PWC. 2016.

RACOUNTEUR. Smart Cities. Retrieved from https://raconteur.uberflip.com/i/798678smart-cities-special-report-2017 Accessed on March 19, 2017.

RATTI, Carlo and Matthew CLAUDEL. The City of Tomorrow: Sensors, Networks, Hackers, and the Future of Urban Life. Boston: Yale University Press. 2016.

REPLICATE. Retrieved from https://replicateproject.eu/cities/san-sebastian/. Accessed on December 24, 2018.

RICS. Smart Cities, Big Data and The Built Environment: What's Required? Reading: University of Reading. 2017.

Rockefeller 100 Resilient Cities. Retrieved from http://www.100resilientcities.org/. Accessed on March 21, 2017.

ROSSI, Ugo. "Fake Friends: The Illusionist Revision of Western Urbanology at the Time of Platform Capitalism". Urban Studies. 2018. (Forthcoming)

ROSSI, Ugo. "The Variegated Economics and the Potential Politics of the Smart City". Territory, Politics, Governance. 4(3):337353. 2016.
SABATO, Sebastiano; Bart VANHERCKE and Gert VERSCHRAEGEN. "Connecting Entrepreneurship with Policy Experimentation? The EU Framework for Social Innovation," Innovation: The European Journal of Social Science Research 30(2):147-167. 2017.

SATYAM, Amitabh and Igor CALZADA. The Smart City Transformations. New Delhi: Bloomsbury Academic and Professional Publishing. 2017.

SCHOLZ, Trebor. Platform Cooperativism: Challenging the Corporate Sharing Economy. New York: Rosa Luxemburg Stiftung. 2016.

SCHUURMAN, Dimitri; Lieven DE MAREZ; Pieter Ballon. "The Impact of Living Lab Methodology on Open Innovation Contributions and Outcomes," Technology Innovation Management Review 1(6):7-16. 2016.

SHARING CITIES. Retrieved from www.sharingcities.eu. Accessed on December 24, 2018.

SHILTON, Katie. "When They Are Your Big Data: Participatory Data Practices as a Lens on Big Data," in Cassidy SUGIMOTO; Hamid R. EKBIA; Michael MATTIOLI. (Eds) Big Data is Not a Monolith. Boston: MIT Press. 2016.

SHIN, Yongjun and Donghee SHIN.

"Modelling Community Resources and Communications Mapping for Strategic InterOrganizational Problem Solving and Civic Engagement". Journal of Urban Technology 23(4): 47-66. 2016.

SIDEWALK LABS, Digital Governance Proposals for DSAP Consultation. Retrieved from https://waterfrontoronto.ca/ $\mathrm{nbe/wcm/connect/waterfront/41979265-}$ 8044-442a-9351-e28ef6c76d70/18.10.15 SWT_Draft+Proposals + Regarding+Data+U $\overline{s e}+$ and + Governance. pdf?MOD $=$ AJPERES. Accessed on December 10, 2018.

SMARTENCITY. Retrieved from https://smartencity.eu/about/lighthousecities/vitoria-gasteiz-spain/ . Accessed on December 24, 2018.

SMARTERTOGETHER. Retrieved from www.smarter-together.eu. Accessed on December 24, 2018.

SMARTICIPATE. Open Governance in the Smart City - a scoping report. Brussels: European Commission. 2016. 
Calzada Mugica, Igor: Deciphering Smart City Citizenship: The Techno-Politics of Data and Urban...

SMART URBAN INTERMEDIARIES. Connecting people. Changing communities. Glasgow: European Commission. 2018. Retrieved from http://www.smart-urban-intermediaries.com/ Accessed on December 10, 2018.

SOLON, Olivia. George Soros: Facebook and Google a menace to society. The Guardian. Retrieved from https://www.theguardian.com/ business/2018/jan/25/george-soros-facebookand-google-are-a-menace-to-society?CMP =sh are_btn_tw. Accessed on January 28, 2018.

SPILHAUS, Daedalus. "The Experimental City," Daedalus 96(1129-1141). 1964

SRNICEK, Nick. Platform Capitalism.

Cambridge: Polity. 2017.

STARDUST. Retrieved from

https://stardustproject.eu/cities/pamplona/. Accessed on December 24, 2018.

STUCKE, Maurice E. and Allen P. GRUNES. Data-Opolies. Retrieved from

https://ssrn.com/abstract $=2927018>$ or <http://dx.doi.org/10.2139/ssrn.2927018. Accessed on March 3, 2017.

SUBIRATS, Joan. The Commons: Beyond the market vs. state dilemma, Open Democracy. Retrieved from https://www.opendemocracy. net/joan-subirats/commons-beyond-market-vsstate-dilemma. Accessed on November 10, 2016.

SUBIRATS, Joan and Cesar RENDUELES. LoS bienes comunes ¿Oportunidad o espejismo? Barcelona: Icaria. 2016.

SUSSKIND, Jamie. Future Politics: Living Together in a World Transformed by Tech. Oxford: Oxford University Press. 2018.

TELEFÓNICA. Manifiesto por un Nuevo Pacto Digital: Una digitalización centrada en las personas. Madrid: Telefónica. 2018.

THOMAS, Vanessa; Ding WANG; Louise MULLAGH; Nick DUNN. "Where's Wally? In Search of Citizen Perspectives on the Smart City," Sustainability 8(3):207. 2016.

TONURIST, Piret; Rainer KATTEL; Veiko LEMBER. "Innovation Labs in the Public Sector: What they are and What they Do?" Public Management Review. 1-25. 2017.

TRANOS, Emmanouil and Drew GERTNER. "Smart Networked Cities?," Innovation: The European Journal of Social Science Research. 25(2). 175-190. 2012.
UK GOVERNMENT. Future of Cities: Foresight for Cities. A Resource for Policy-Makers. London: UK Government. 2016.

UNIVERSIDAD DE DEUSTO. Declaración Deusto Derechos Humanos en Entornos Digitales. Retrieved from https://www. deusto. es/cs/Satellite/deusto/es/universidaddeusto/sobre-deusto-0/derechos-humanos-e n-entornos-digitales. Access on December 10, 2018.

Urb@exp (Learning from Urban Experiments). Retrieved from http://www.urbanexp.eu/. Accessed on March 21, 2017.

URBAN LAB +. Retrieved from http://www.urbanlab.com/. Accessed on March 21, 2017.

URBAN I LAB. Retrieved from http://ajuntament.barcelona.cat/digital/en/digi tal-innovation/urban-i-lab. Access on January 29, 2018.

URBAN TRANSFORMATIONS. Rethinking the Urban Commons in European CityRegions. Retrieved from http://www.urbantransformations.ox.ac.uk/event/rethinking-theurban-commons-in-european-city-regions/ Accessed on January 29, 2018.

URBAN TRANSFORMATIONS. Urban Living Partnerships (2017) Retrieved from http://www.urbantransformations.ox.ac.uk/abo ut/the-urban-living-partnerships/. Accessed on March 20, 2017.

URRY, John. The Future of Urban Living Paper Commissioned by the Forsight Future of Cities Programme. Retrieved from https://futureo-fcities.blog.gov.uk/2014/07/ 11/living-in-the-city/. Accessed on March 21, 2014.

VAN DER ZWAN, Joleen, VAN DOORN, Menno, DUIVESTEIN, Sander and Thijs PEPPING. Digital Happiness: In Code We Trust. SogetiLabs.

WAAG. A Manifesto for Smart Citizens. Retrieved from http://waag.org/en/ blog/manifesto-smart-citizens. Accessed on December 20, 2016.

WACHTER-BOETTCHER, Sara. Technically Wrong: Sexist Apps, Biased Algorithms, and Other Threats of Toxic Tech. London: W. W. Norton \& Company. 2017.

WANYAMA, Frederik. Cooperatives and the Sustainable Development Goals: A 
Calzada Mugica, Igor: Deciphering Smart City Citizenship: The Techno-Politics of Data and Urban...

Contribution to the Post-2015 Development

Debate a Policy Brief. ILO - International Labour Organization. 2014.

WEBB, Stefan and Euan MILLS. User

Research Insights Report: Prototyping the

Future of Planning. London: Future Cities

Catapult. 2016.

WEST, Joel and Marcel BOGERS. "Open

Innovation: Current Status and Research Opportunities," Innovation 19(1):43-50. 2016.

THE ATLANTIC. Why I am not a maker".

Retrieved from https://www.theatlantic.com/ technology/archive/2015/01/why-i-am-not-amaker/384767/. Accessed on March 21, 2015.

WILLIS, Katharine S. and Alessandro AURIGI. Digital and Smart Cities. Oxon: Routledge, 2018.

WIRED. Yuval Noah Harari and Tristan Harris intertwined by Wired. 2018. Retrieved from https://www.youtube.com/watch?v=vOsWeLZ 8PXg Accessed on December 10, 2018.

ZANOUDA, Tahar; Noora AI EMADI; Sofiane ABBAR; Jaideep SRIVASTAVA. "The Quantified City: Sensing Dynamics in Urban Setting". 2017. arXiv preprint arXiv:1701.04253. 